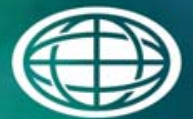

Savannah River

National Laboratory ${ }^{m}$

OPERATED BY SAVANNAH RIVER NUCLEAR SOLUTIONS

\title{
Glycolate Impacts Testing with New Guanidine (TiDG) Solvent for MCU
}

C. A. Nash

T. B. Peters

A. L. Washington, II

F. F. Fondeur

September 2014

SRNL-STI-2014-00369, Rev. 0 
SRNL-STI-2014-00369

Revision 0

\section{DISCLAIMER}

This work was prepared under an agreement with and funded by the U.S. Government. Neither the U.S. Government or its employees, nor any of its contractors, subcontractors or their employees, makes any express or implied:

1. warranty or assumes any legal liability for the accuracy, completeness, or for the use or results of such use of any information, product, or process disclosed; or

2. representation that such use or results of such use would not infringe privately owned rights; or

3. endorsement or recommendation of any specifically identified commercial product, process, or service.

Any views and opinions of authors expressed in this work do not necessarily state or reflect those of the United States Government, or its contractors, or subcontractors.

\section{Printed in the United States of America \\ Prepared for U.S. Department of Energy}




\section{Glycolate Impacts Testing with New Guanidine (TiDG) Solvent for MCU}

C. A. Nash

T. B. Peters

A. L. Washington, II

F. F. Fondeur

September 2014

Prepared for the U.S. Department of Energy under 


\section{REVIEWS AND APPROVALS}

\section{AUTHORS:}

C. A. Nash, SRNL-ERPS-AC\&PT

Date

T. B. Peters, SRNL-ERPS-AC\&PT

Date

A. L. Washington II, SRNL-ERPS-AC\&PT

Date

F. F. Fondeur, SRNL-ERPS-S\&AS

Date

TECHNICAL REVIEW: (Reviewed per E7 2.60)

C. J. Martino, SRNL-ERPS-AC\&PT

Date

\section{APPROVALS:}

F. M. Pennebaker, Manager, SRNL-ERPS-AC\&PT

Date

D.H. McGuire, Manager, SRNL-ERPS-PTP

Date

S. L. Marra, Manager, SRNL-ERPS

Date

E. J. Freed, Manager, SRR Facility Engineering

Date

D. J. Martin, Manager, Tank Farm Facility Engineering

Date 


\section{EXECUTIVE SUMMARY}

Savannah River Remediation (SRR) is evaluating the use of glycolic acid as an alternate reductant (versus formic acid) in a flowsheet for the Defense Waste Processing Facility (DWPF). DWPF recycle would provide a pathway for some glycolic acid to be present in feed to Modular Caustic Side Solvent Extraction Unit (MCU). This report evaluated glycolate impacts on MCU polymer seal material, organic phase separation and glycolic carryover, and Extraction, Scrub, and Strip (ESS), finding no detrimental impacts in any case.

The effects of glycolate on several aspects of the solvent extraction system used at MCU have been examined. The conclusions are as follows:

- The presence of up to $10,000 \mathrm{ppm}$ of sodium glycolate in a caustic salt solution, or in a neutral $\mathrm{pH}$ simulant has no discernable effect on the separation behavior of the solvent/aqueous mixtures, as tested by dispersion experiments.

- After contacting the organic solvent with aqueous solutions containing up to $10,000 \mathrm{ppm}$ of glycolate, there was no detectable influx of glycolate into the solvent.

- Contacting various organic polymers used at MCU with aqueous solutions containing glycolate showed that there was no glycolate induced swelling in any of the polymer samples.

- Extraction, Scrub, Strip (ESS) testing with actual tank samples spiked with up to 10,000 ppm of glycolate showed no effects on solvent performance. 


\section{TABLE OF CONTENTS}

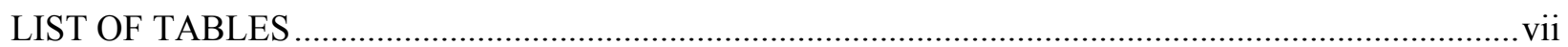

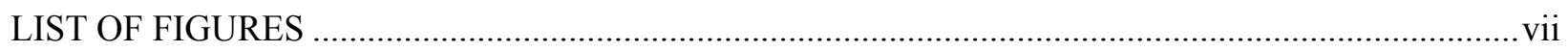

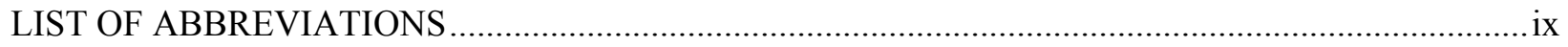

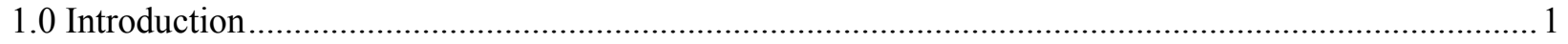

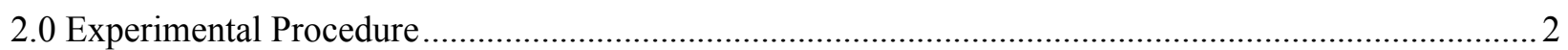

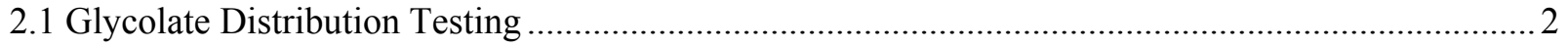

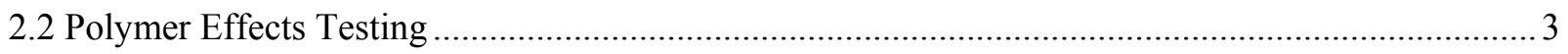

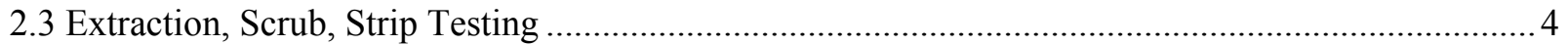

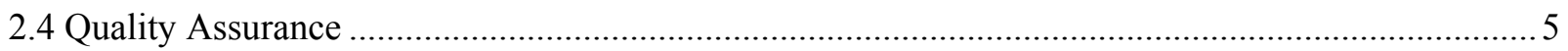

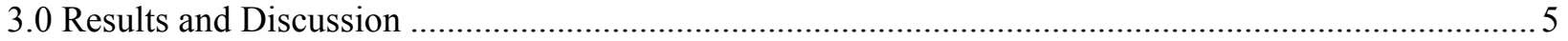

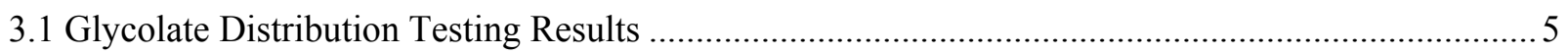

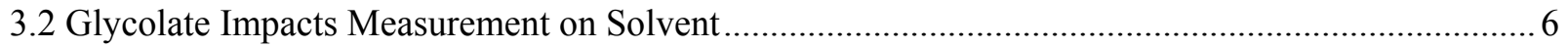

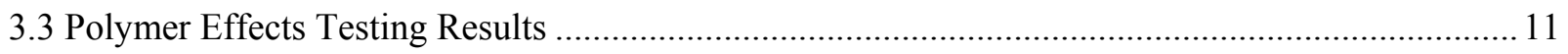

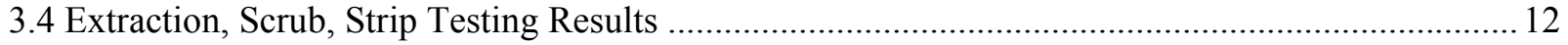

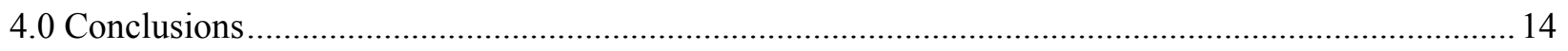

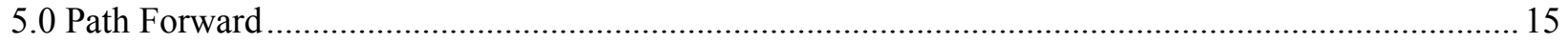

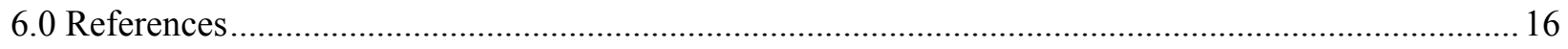

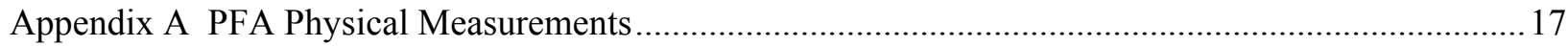

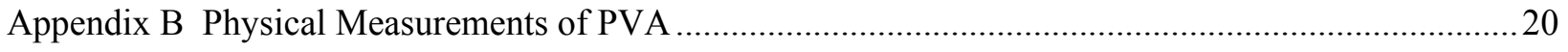

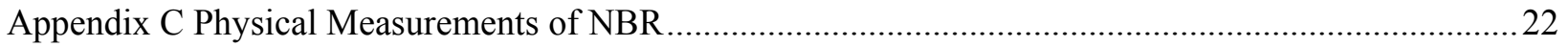




\section{LIST OF TABLES}

Table 1-1. Nominal Component Concentration in the Three Solvents ................................................. 1

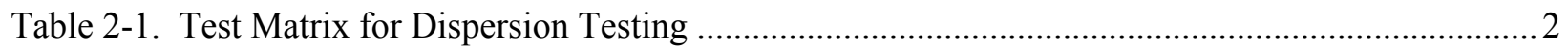

Table 2-2. Composition of 5.6 M Sodium Salt Simulants ....................................................................... 2

Table 2-3. Polymeric Materials Tested ….....................................................................................

Table 3-1. Dispersion Numbers from Simulant Testing ........................................................................ 6

Table 3-2. DI Water Extract pH for Solvents Contacting Caustic Simulants .......................................... 8

Table 3-3. Contact Data for Caustic Simulant/Glycolate..................................................................... 9

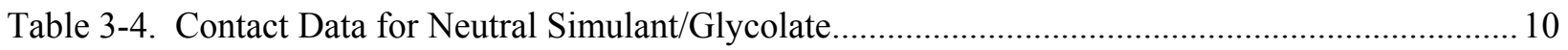

Table 3-5. Contact Data for Control Simulant - No Glycolate.............................................................. 10

Table 3-6. Hansen's prediction of Glycolate interaction with PFA, PVAcetal, and NBR ...................... 12

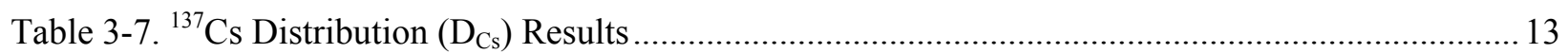

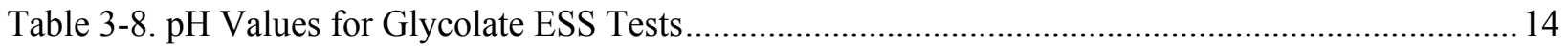

\section{LIST OF FIGURES}

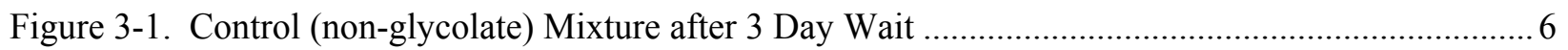

Figure 3-2. Control Solvent Mixture and First Water Wash............................................................... 7

Figure 3-3. Control Solvent Mixture and Second Water Wash ............................................................ 8

Figure A-1. The Thickness of PFA after two months of contact with different aqueous solutions containing Glycolate.

Figure A-2. The diameter of PFA after two months of contact with different aqueous solutions containing Glycolate.....

Figure A-3. The net weight of PFA after two months of contact with different aqueous solutions

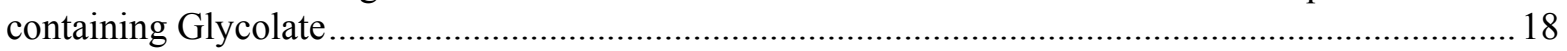

Figure A-4. The density of PFA after two months of contact with different aqueous solutions containing Glycolate.

Figure A-5. The hardness of PFA after two months of contact with different aqueous solutions containing Glycolate.

Figure B-1 The diameter of PVA after two months of contact with different aqueous solutions containing Glycolate. 20 
Figure B-2 The net weight of PVA after two months of contact with different aqueous solutions containing Glycolate

Figure B-3. The density of PVA after two months of contact with different aqueous solutions containing Glycolate.

Figure B-4. The hardness of PVA after two months of contact with different aqueous solutions containing Glycolate

Figure C-1. The thickness of NBR after two months of contact with different aqueous solutions containing Glycolate

Figure C-2. The net weight of NBR after two months of contact with different aqueous solutions containing Glycolate.....

Figure C-3. The hardness of NBR after two months of contact with different aqueous solutions containing Glycolate 


\section{LIST OF ABBREVIATIONS}

\begin{tabular}{|c|c|}
\hline ARP & Actinide Removal Process \\
\hline $\mathrm{CF}$ & Concentration Factor \\
\hline CWT & Caustic Wash Tank \\
\hline $\mathrm{DF}$ & Decontamination Factor \\
\hline DI & Deionized (Water) \\
\hline DSS & Decontaminated Salt Solution \\
\hline DSSHT & Decontaminated Salt Solution Hold Tank \\
\hline ELN & Electronic Laboratory Notebook \\
\hline HPLC & High Performance Liquid Chromatography \\
\hline IC & Ion Chromatography \\
\hline ICPES & Inductively-Coupled Plasma Emission Spectroscopy \\
\hline ICPMS & Inductively-Coupled Plasma Mass Spectroscopy \\
\hline $\mathrm{MCU}$ & Modular Caustic-Side Solvent Extraction Unit \\
\hline NBR & Nitrile Butadiene Rubber \\
\hline NGS & Next Generation Solvent (extractant MAXCalix) \\
\hline MST & Monosodium titanate \\
\hline PFA & PerFluoroalkoxy Alkane \\
\hline PVA & Polyvinyl Acetal \\
\hline PuTTa & Plutonium thenoyl trifluoroacetone scintillation \\
\hline RSD & Relative standard deviation \\
\hline SE & Strip Effluent \\
\hline SEHT & Strip Effluent Hold Tank \\
\hline SHT & Solvent Hold Tank \\
\hline SRAT & Sludge Receipt Adjustment Tank \\
\hline SRNL & Savannah River National Laboratory \\
\hline SVOA & Semi-Volatile Organic Analysis \\
\hline SWPF & Salt Waste Processing Facility \\
\hline TIC/TOC & Total Inorganic Carbon/Total Organic Carbon \\
\hline TOA & trioctylamine \\
\hline TiDG & $\mathrm{N}, \mathrm{N}^{\prime}, \mathrm{N}^{\prime}$ - tris(isotridecyl)guanidine \\
\hline TTQAP & Task Technical and Quality Assurance Plan \\
\hline TTR & Task Technical Request \\
\hline
\end{tabular}




\subsection{Introduction}

This work examines the effect of glycolate on the Modular Caustic Side Solvent Extraction Unit (MCU) process with blend solvent that includes the suppressor N, N', N'tris(isotridecyl)guanidine (TiDG). Glycolic acid is being considered as a reductant to replace formic acid in the Defense Waste Processing Facility (DWPF). ${ }^{1}$ Glycolate sent to the tank farm via DWPF recycle will ultimately be processed through MCU or the Salt Waste Processing Facility (SWPF). Work in this report follows a past effort where process and materials effects of glycolate were examined using MaxCalix as the extractant and a commercial amine LIX ${ }^{\text {TM79 }}$ as the suppressor. ${ }^{2}$ This work addresses past recommendations from that report.

The MCU process previously operated with a four component solvent which removes cesium from clarified salt solution. The previous solvent, designated BOBCalixC6 Based Solvent (or "BOB Solvent"), is comprised of BOBCalixC6 (extractant), trioctylamine (TOA, suppressor), Cs7SB (modifier), and IsoparTM L (diluent). Next Generation Solvent (NGS) utilizes a new extractant and suppressor in MCU; it is a four component mixture comprised of MaxCalix (extractant), N, N', N''- tris(isotridecyl)guanidine (TiDG, the suppressor), Cs-7SB (modifier), and Isopar ${ }^{\mathrm{TM}} \mathrm{L}$ (diluent). The NGS solvent components were introduced to the MCU system in a "concentrate" and blended with the residual volume (95 gallons) of BOBCalixC6 Based Solvent in the MCU solvent hold tank to create the NGS Blend. ${ }^{3}$ Solvent components and concentrations are shown in Table 1-1.

\section{Table 1-1. Nominal Component Concentration in the Three Solvents}

\begin{tabular}{|c|c|c|c|}
\hline \multirow{2}{*}{ Component } & \multicolumn{3}{|c|}{ Nominal component concentration in the three Solvents $(\mathrm{mg} / \mathrm{L})$} \\
\hline & BOB Solvent & NGS Blend & NGS \\
\hline BOBCalix & 8,050 & 4,030 & 0 \\
\hline MAXCalix & 0 & 44,400 & 47,800 \\
\hline Modifier & 254,000 & 169,000 & 169,000 \\
\hline TOA & 1,060 & 530 & 0 \\
\hline TiDG & 0 & 1,550 & 1,550 \\
\hline Isopar $^{\mathrm{TM}} \mathrm{L}$ & balance & balance & balance \\
\hline
\end{tabular}

The introduction of glycolic acid to potentially replace formic acid as a reducing chemical in the Sludge Receipt Adjustment Tank (SRAT) process prompted a material compatibility review of existing material. To that end a review of previous materials compatibility testing of the materials used at MCU revealed that three polymers needed further testing in the presence of glycolate: PerFluoroalkoxy Alkane (PFA), Polyvinyl Acetal (PVA), and Nitrile Butadiene Rubber (NBR). This work investigated the compatibility of these polymers in $5.6 \mathrm{M}$ sodium salt simulant and in $10 \mathrm{mM}$ boric acid both containing up to $10,000 \mathrm{ppm}$ sodium glycolate to ensure the MCU foreign exclusion material requirements will be meet. The MCU foreign material exclusions measures ensure that unacceptable levels of contamination that could cause MCU to not meet the decontamination factor for cesium or processing delays are not added to the MCU feed without evaluation.

This work was performed at the request of SRR Engineering and was controlled by a Task Technical and Quality Assurance Plan (TTQAP). ${ }^{4}$ 


\subsection{Experimental Procedure}

Procedures for the three subtasks distribution testing, polymer tests, and ESS tests, are provided in Sections 2.2 to 2.4 below.

\subsection{Glycolate Distribution Testing}

This subtask included dispersion testing, intense homogenization, and deionized water (DI) extraction to see if glycolate in high-sodium simulants affects phase separation and if detectable glycolate is taken up into the solvent. The basic liquids to be used here were (1) new made-fromscratch NGS blend solvent, (2) a neutral version of $5.6 \mathrm{M}$ sodium simulant, and (3) the typical caustic 5.6 M sodium simulant. The made-from-scratch NGS blend solvent was made by work instructions, using reagents as shown in Table 1-1 of the previous section. Portions of simulants were adjusted to include 5,000 and $10,000 \mathrm{mg} / \mathrm{L}$ glycolate, added as sodium glycolate salt which was then dissolved. The test matrix for dispersion testing is shown in Table 2-1.

Table 2-1. Test Matrix for Dispersion Testing

\begin{tabular}{|l|l|}
\hline Salt Simulant & Glycolate levels, mg/L \\
\hline Neutral 5.6 M Na+ & $5,000,10,000$ \\
\hline Caustic 5.6 M Na+ & Zero (control), 5,000, 10,000 \\
\hline
\end{tabular}

Compositions of the 5.6 M sodium aqueous solutions are given in Table 2-2 below. Note that neither simulant has potassium or aluminum. The caustic simulant SWS-1-2010 was available from previous work. ${ }^{2}$ The absence of potassium and aluminum is not expected to affect results, similar to what was done in that previous work. The neutral simulant was formulated so that $\mathrm{pH}$ would be close to neutral, giving a much different environment for glycolate to possibly be taken up into the solvent. Note that the $\mathrm{pH}$ range tested here, neutral and high, give a very wide bound on aqueous feed $\mathrm{pH}$. Aqueous feed is at high $\mathrm{pH}$ and is the only source of glycolate that may challenge MCU; scrub and strip $\mathrm{pH}$ ranges are not relevant to this test. Both scrub caustic and strip acid coming into the plant are reagent feeds and contain no glycolate.

For the neutral simulant the free hydroxide was replaced with nitrate, and the carbonate was replaced with bicarbonate to keep the $\mathrm{pH}$ near neutral. The density of SWS-1-2010 was measured to be $1.274+/-0.002 \mathrm{~g} / \mathrm{mL}$ at room temperature. The density of the neutral simulant was $1.284 \mathrm{~g} / \mathrm{mL}$ in one measurement.

Table 2-2. Composition of 5.6 M Sodium Salt Simulants

\begin{tabular}{|l|c|c|}
\hline \multicolumn{1}{|c|}{ Ion } & SW-1-2010 & Neutral Simulant \\
\hline & Molarity & Molarity \\
\hline Sodium & 5.6 & 5.6 \\
\hline Free $\mathrm{OH}$ & 1.33 & 0 (pH 7 to 7.5) \\
\hline Nitrate & 2.9 & 4.26 \\
\hline Nitrite & 0.149 & 0.149 \\
\hline Sulfate & 0.581 & 0.581 \\
\hline Added Carbonate & 0.029 & $0.029^{*}$ \\
\hline
\end{tabular}

*this was added as bicarbonate to preserve neutral $\mathrm{pH}$ 
Solvent:Aqueous (O:A) ratios paralleled those of the MCU NGS flow sheet to produce a concentration effect if glycolate carries over from caustic feed to strip. The extraction bank O:A ratio of 1:4 was used for solvent:5.6 M sodium contacts for dispersion and glycolate uptake. A $20 \mathrm{~mL}: 5.3 \mathrm{~mL}$ (or 3.75:1) O:A ratio was used for stripping the solvent with DI water in the current testing. These differ from the extraction O:A ratio of 1:3 and O:A ratio of 5:1 for stripping under the BOBCalixC6 flow sheet previously run at MCU. While physical aqueous carryover is not plant typical, any means of glycolate dissolution into the solvent would suggest what MCU might see if glycolate is present in its aqueous feed. Use of the given O:A ratios in lab testing gave the tendency to concentrate any species that dissolved in the solvent, making those species more visible in strip samples.

Dispersion testing was defined by Leonard and is a means of quantifying separation ability of organic and aqueous liquid phases. ${ }^{6}$ The SRNL implementation of dispersion testing is found in a Work Instruction. ${ }^{7}$

Literature has indicated possible mechanisms for dissolution of glycolate in organic solvents. Inci studied a solvent system that included various organic solvents including the aliphatic solvent heptane, amines including trioctylamine, and glycolic acid. ${ }^{8}$ While the heptane uptake of glycolic acid was relatively weak, it was measureable, and the mechanism likely involved organic phase complexation of the glycolic acid with the organic amine. In further work Inci and a coworker used octanes along with a wider selection of solvents and again found measurable uptake. ${ }^{9}$ The extractant was pure water though $\mathrm{pH}$ was likely acidic given the release of glycolic acid into the water. In all cases here the least polar solvents took up the least glycolate compared with the more polar solvents like methyl isobutyl ketone. The literature appeared relevant to the issue of glycolate in solvent because amines in the guanidine and possible degradation products might increase glycolate solubility in the organic phase.

The findings from the literature above suggested that water extraction of NGS would allow determination of glycolate content in solvent.

After dispersion testing, the aqueous/organic liquids (samples and controls) were homogenized within their $100-\mathrm{mL}$ graduated cylinders to further ensure good contact between glycolatecontaining aqueous phases and the solvent phases. Homogenization was performed with a variable speed Tissue Tearor ${ }^{\mathrm{TM}}$, Model 985370, (Biospec Products, Inc.) for 90 seconds each. After three-day waiting periods for separation, the solvent phases were extracted twice with DI water. DI water sample pH's were measured, then the samples were submitted for atomic absorption for sodium and also IC anions including glycolate. The work thus evaluated glycolate carryover to the DI water extractions. The presence of sodium, sulfate and nitrate in the water would indicate physical carryover, allowing an estimate of glycolate from carryover. Proportions similar to the starting simulant compositions would indicate physical carryover, and excess glycolate would indicate partitioning into the solvent.

\subsection{Polymer Effects Testing}

The polymeric materials tested are shown in Table 2-3. Personnel procured commercially available polymeric materials which were used as received. In the case of PVA and PFA, these materials were received as a solid and hollow tube respectively. The PVA and PFA cylindrical material was cut into a manageable size to fit into a $15 \mathrm{~mL}$ glass vial (typical piece height was 6 $\mathrm{mm})$. 
The polymer pieces were weighed and dimensions measured before exposure to the aqueous solutions (both salt simulant and $10 \mathrm{mM}$ boric acid) containing glycolate $(10,000 \mathrm{ppm})$. The data was stored electronically for easier retrieval in NB \# A2869-00071-04. The polymers then were inserted in $15 \mathrm{~mL}$ glass vials (with Teflon caps) containing $10 \mathrm{~mL}$ of solutions. Duplicate samples were prepared and tested.

Table 2-3. Polymeric Materials Tested

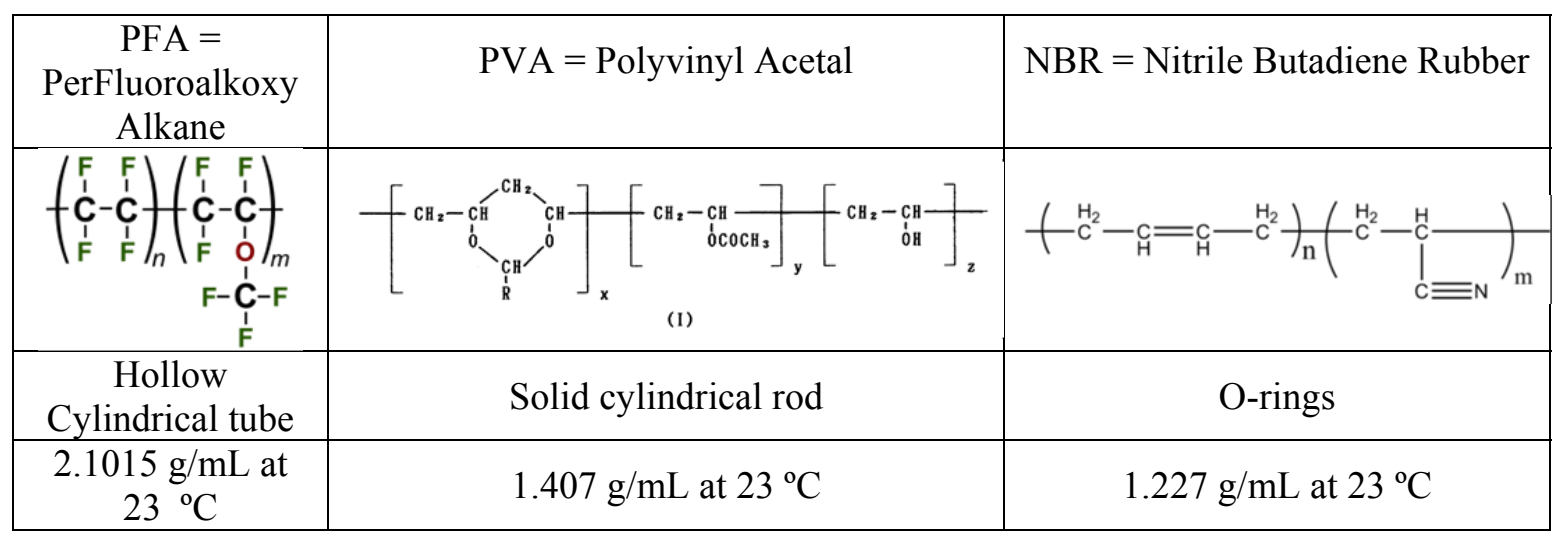

Some polymers pieces were placed in NGS to determine if the NGS facilitates glycolate uptake. After one week of exposure to NGS, the polymer pieces were removed, the excess NGS was removed, and the polymer pieces were placed in salt simulant (see Table 2-2) and boric acid solutions containing up to $10,000 \mathrm{ppm}$ glycolate. The vials containing $10 \mathrm{mM}$ boric acid were kept at $33+/-1{ }^{\circ} \mathrm{C}$ while the remaining vials were kept at $23+/-1{ }^{\circ} \mathrm{C}$. After a few days, the polymer pieces were removed from the aqueous solutions (and NGS), measured (weight and physical dimensions), and the data recorded. These measurements were done twice a week and the entire test ran for two months. The thicknesses of the samples were sufficiently small that any interaction with glycolate will be at steady state at the end of two months.

\subsection{Extraction, Scrub, Strip Testing}

For the ESS test, the MCU solvent samples were prepared from a composite of MCU samples received after the implementation of the NGS blend solvent. These samples were received as a part of the monthly solvent analysis and are used for the study per the Task Technical Request (TTR). Several sources of previously delivered NGS blend solvent were delivered to SRNL and subsequently composited to one container. The following solvent hold tank (SHT) samples were used:

MCU-13-1473, 1474, -1475, -1484, -1485, -1486,

MCU-14-38, -39, - -40, -53, -54, -55, -81, -82, -83, -214, -215, -216.

After a sample was removed for TiDG analysis, this left $77 \mathrm{~mL}$ of solvent composite. Based upon the TiDG analysis results, the solvent was deficient in TiDG. To recify this, $5 \mathrm{~mL}$ of a freshly prepared blend solvent was prepared in lab, with enough additional TiDG added to it such that when the $5 \mathrm{~mL}$ was combined with the $77 \mathrm{~mL}, 82 \mathrm{~mL}$ of solvent was prepared that had the proper chemical composition, including TiDG at $3 \mathrm{mM}$. This composite sample was used as the organic feed for the ESS testing. The ${ }^{137} \mathrm{Cs}$ activity of the composite solvent was measured to be 
$2.38 \mathrm{E}+05 \mathrm{dpm} / \mathrm{mL}$. The aqueous feed sample LWHT-1 was from the Late Wash Hold Tank (LWHT) of the 512-S facility as a part of the analyses of several Tank $49 \mathrm{H}$ variable depth samples. This material was previously analyzed. ${ }^{10}$ Portions of this aqueous material were spiked to the appropriate concentrations of sodium glycolate $(0,5,000$, and $10,000 \mathrm{mg} / \mathrm{L})$. No solids were observed before or after the glycolate spike in the any of the aqueous feeds. The LWHT-1 material is already filtered after being contacted with MST in the $96 \mathrm{H}$ strike tanks.

Using these materials, the researchers performed three ESS tests. All of the tests used the same general protocol ${ }^{11}$ as used in the previous Macrobatch testing, with two deviations. All aqueous feeds used a nominal starting volume of $80 \mathrm{~mL}$ from the aqueous materials described above and $20 \mathrm{~mL}$ of previously contacted NGS blend composite solvent also described above. For all tests, the scrub and strip solutions were $0.025 \mathrm{M} \mathrm{NaOH}$ and $0.01 \mathrm{M}$ boric acid, respectively. Normally, there are 1 extraction, 2 scrub, and 3 strips steps. However, one of the strip steps was performed using scrub solution. Thus, 1 extraction, 3 scrub, and 2 strip steps were performed for each test. As such, each step in each ESS test is referred to as it was performed, not as it was intended.

Confirmation of $\mathrm{pH}$ was performed by $\mathrm{pH}$ strip paper with a precision limited to about $+/-1 \mathrm{pH}$ for the strips we used. Organic and aqueous samples from each step including extraction, three scrubs, and two strips were removed and sent to ADS for gamma spectroscopy. Due to their low activity, the aqueous samples were submitted without dilution for analysis. However, the organic samples ( $\sim 0.9$ grams) were each diluted with approximately $4 \mathrm{~mL}$ of Isopar ${ }^{\mathrm{TM}} \mathrm{L}$ to reduce the external dose and maintain radiological hood limits in ADS. The organic dilution factors have been addressed in the $\mathrm{D}_{\mathrm{Cs}}$ value calculations. A cell blank is not normally used in the radiochemical portion of this analysis since Cs-137 is fairly high in the samples and therefore is not addressed in this report.

\subsection{Quality Assurance}

The work instructions and data for this work are recorded in electronic laboratory notebooks (ELN). These include experiment 03 of ELN T7692-00085 and experiment 02 of A4571-00085. Requirements for performing reviews of technical reports and the extent of review are established in Manual E7 2.60. SRNL documents the extent and type of review using the SRNL Technical Report Design Checklist contained in WSRC-IM-2002-00011, Rev 2.

\subsection{Results and Discussion}

\subsection{Glycolate Distribution Testing Results}

The dispersion testing found good to excellent phase separation in all cases. Leonard's test method evaluated phase separation as excellent for dispersion numbers around $1.6 * \mathrm{E}-03$, good for $8 * \mathrm{E}-04$, fair for $4 * \mathrm{E}-04$ and poor for $2 * \mathrm{E}-04$. Table 3-1 below shows that dispersion number equals or exceeds about $8 * \mathrm{E}-04$ in all cases, so that phase coalescence is not expected to be a problem in stage wise operations. There are thus no glycolate impacts based on this test.

There was a marked difference between the caustic aqueous simulant and the neutral simulant results. It is not known why the neutral version of the simulant displayed excellent phase separation. The dispersion results for the caustic simulant are comparable to past testing with caustic simulants. ${ }^{2}$ 
Table 3-1. Dispersion Numbers from Simulant Testing

\begin{tabular}{|c|c|c|c|c|}
\hline Sample & $\begin{array}{c}\text { Cylinder } \\
\text { Height, } \\
\text { inches }\end{array}$ & $\begin{array}{c}\text { First } \\
\text { Dispersion } \\
\text { time, seconds }\end{array}$ & $\begin{array}{c}\text { Second } \\
\text { Dispersion } \\
\text { time, seconds }\end{array}$ & $\begin{array}{c}\text { Average Dispersion } \\
\text { Number }\end{array}$ \\
\hline Caustic 5,000 ppm & 7.13 & 184.3 & 175.1 & $7.56 \mathrm{E}-04$ \\
\hline Caustic 10,000 ppm & 7.25 & 160.0 & 170.6 & $8.30 \mathrm{E}-04$ \\
\hline Neutral 5,000 ppm & 7.13 & 78.2 & 72.4 & $1.81 \mathrm{E}-03$ \\
\hline Neutral 10,000 ppm & 7.25 & 82.7 & 86.0 & $1.62 \mathrm{E}-03$ \\
\hline $\begin{array}{c}\text { Caustic Control, no } \\
\text { glycolate }\end{array}$ & 7.13 & 174.2 & 169.9 & $7.90 \mathrm{E}-04$ \\
\hline
\end{tabular}

\subsection{Glycolate Impacts Measurement on Solvent}

After dispersion testing of Section 3.1 was complete, it was found that while bulk separation occurred quickly, as in the dispersion tests, the organic phase retained a milky haze. All cylinders were then allowed to sit undisturbed at room temperature for three days. Figure 3-1 shows the appearance of the control cylinder (no glycolate) after three days, and the other samples were similar. With the three days of settling, most of the haze was removed, but some was still visible as in the figure. The effect of gravity is apparent as the upper part of the organic layer was clear and the haze increased with depth into the organic layer.

Figure 3-1. Control (non-glycolate) Mixture after 3 Day Wait

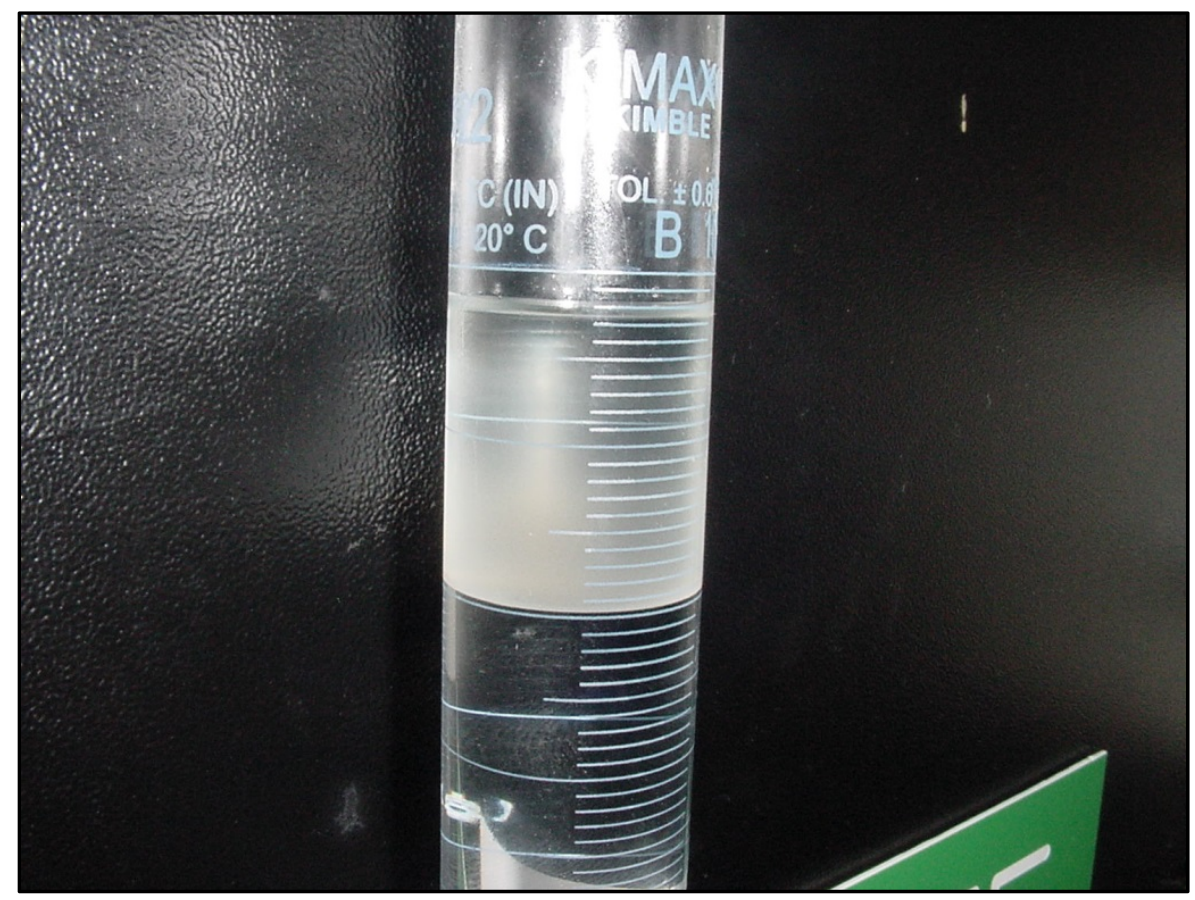


Each organic phase was extracted twice with DI water. Separatory funnels were shaken by hand. Figure 3-2 shows that the organic phase got hazy again. It was extracted with a second volume of DI water several hours later. Figure 3-3 shows that the organic layer was again hazy. This suggests that some physical carryover of the aqueous phase might be seen in this work. Previous solvent contact work was often done in Teflon separatory funnels where haze would be hard to see, so this behavior is likely normal. In addition the work with full size contactors noted the same behavior. ${ }^{12}$ See Section 4.2 of that reference. Those authors also noted that the cloudy appearance of solvent would clarify with days of standing.

Figure 3-2. Control Solvent Mixture and First Water Wash

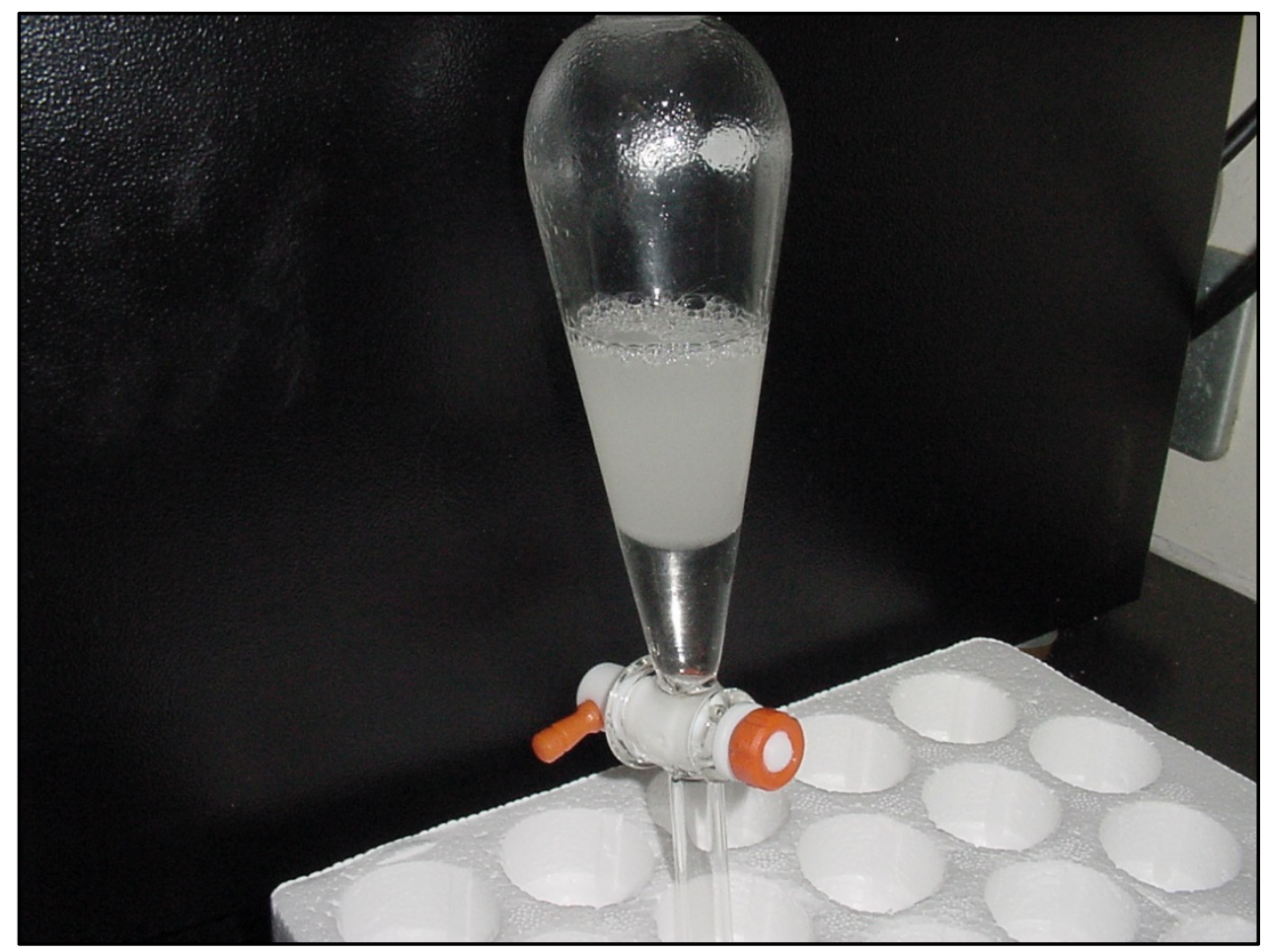


Figure 3-3. Control Solvent Mixture and Second Water Wash

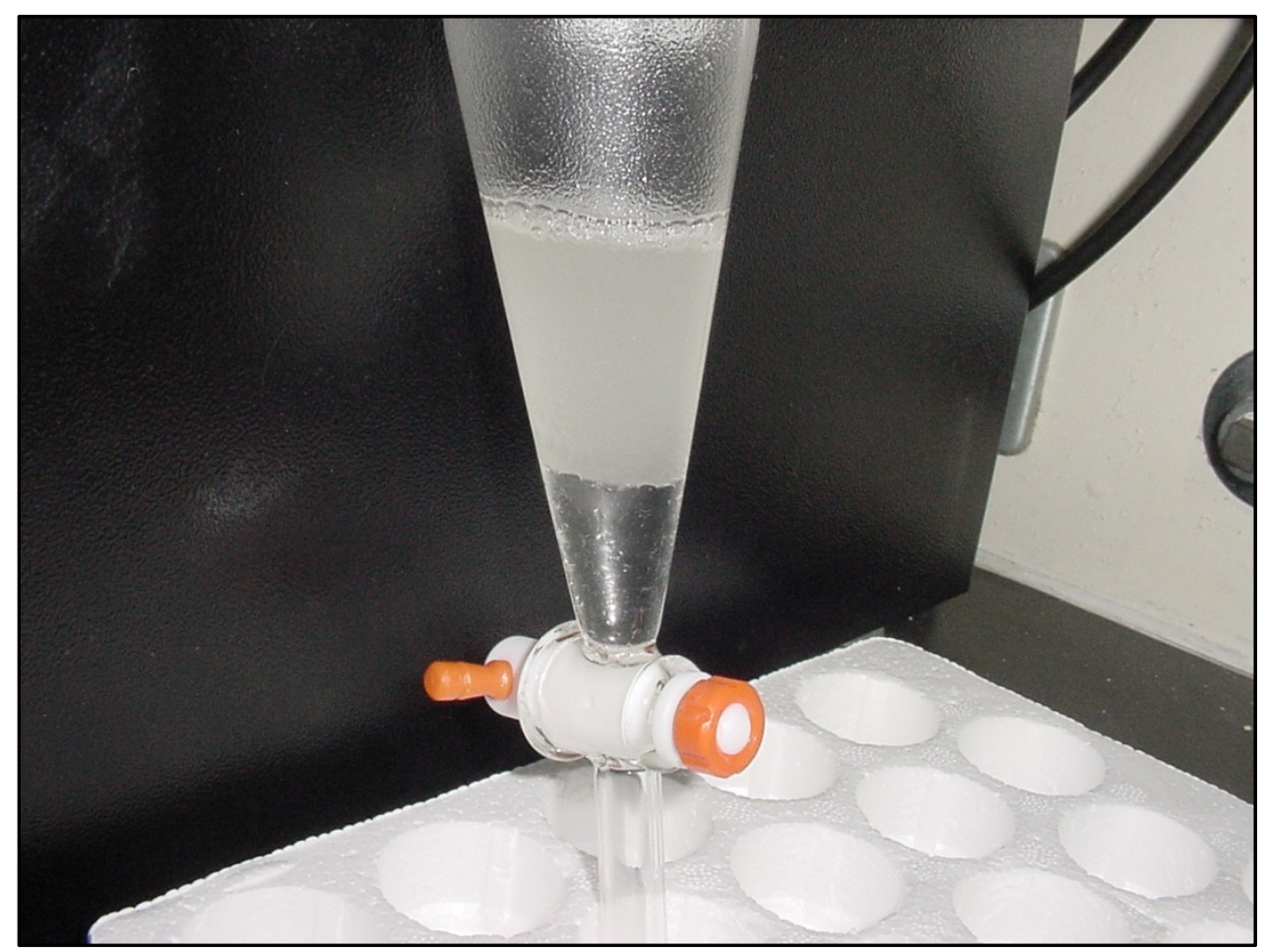

Both water extracts were submitted as samples for analysis of anions including glycolate, and sodium and $\mathrm{pH}$ were also measured. $\mathrm{pH}$ data for the caustic simulant are shown in Table 3-2. $\mathrm{pH}$ indicated that there was some type of carryover of trace caustic material, though the second water wash completely removed it from the organic layer.

Table 3-2. DI Water Extract pH for Solvents Contacting Caustic Simulants

\begin{tabular}{|c|c|c|}
\hline $\begin{array}{c}\text { Simulant Glycolate } \\
\text { Level }\end{array}$ & $\begin{array}{c}\text { First Water Wash } \\
\mathrm{pH}\end{array}$ & $\begin{array}{c}\text { Second Water Wash } \\
\mathrm{pH}\end{array}$ \\
\hline $0 \mathrm{ppm}($ Control $)$ & $11.5+/-0.5$ & $7.0+/-0.5$ \\
\hline $5,000 \mathrm{ppm}$ & $12.5+/-0.5$ & $7.0+/-0.5$ \\
\hline $10,000 \mathrm{ppm}$ & $13.0+/-0.5$ & $7.0+/-0.5$ \\
\hline
\end{tabular}

Table 3-3 provides the extract composition data from the 5,000 and 10,000 ppm glycolate caustic (SWS-1-2010) simulant. The first two rows give the analyzed and expected composition of the simulant itself, plus some ratios that can be used to gauge physical carryover of this material. There were sufficient species in water wash A (the first water wash for the solvent after dispersion/homogenizing/3-day separation with simulant) to determine carryover. Data for the sodium to nitrate ratio were distinct enough that the ratio indicated a small amount of physical 
carryover. The other ratios indicated that sulfate and glycolate carryover was less than what would be expected from physical carryover.

Table 3-3. Contact Data for Caustic Simulant/Glycolate

\begin{tabular}{|c|c|c|c|c|c|c|c|c|}
\hline Simulant & Sodium & Nitrite & Nitrate & Sulfate & Glycolate & $\mathrm{Na} / \mathrm{S}$ & $\mathrm{Na} / \mathrm{NO} 3$ & $\mathrm{Na} /$ Glycol \\
\hline $\begin{array}{l}5,000 \\
\text { ppm } \\
\text { Glycolate }\end{array}$ & 123,000 & 6,890 & 180,000 & 56,500 & 6,290 & 6.53 & 0.68 & 19.6 \\
\hline Target & 128,700 & 6,855 & 179,800 & 55,810 & 5,000 & 6.91 & 0.72 & 25.8 \\
\hline $\begin{array}{l}\text { Water } \\
\text { Wash A }\end{array}$ & 850 & 30 & 1,130 & 92 & $<10$ & 25.4 & 0.75 & $>85$ \\
\hline $\begin{array}{l}\text { Water } \\
\text { Wash B }\end{array}$ & $\mathrm{NM}$ & $<10$ & 46 & 11 & $<10$ & & & \\
\hline $\begin{array}{l}10,000 \\
\text { ppm } \\
\text { Glycolate }\end{array}$ & 123,000 & 6,970 & 184,000 & 59,100 & 9,170 & 6.24 & 0.67 & 13.4 \\
\hline Target & 128,700 & 6,855 & 179,800 & 55,810 & 10,000 & 6.91 & 0.72 & 12.9 \\
\hline $\begin{array}{l}\text { Water } \\
\text { Wash A }\end{array}$ & 2,720 & 122 & 3,530 & 841 & 141 & 8.72 & 0.77 & 19.4 \\
\hline $\begin{array}{l}\text { Water } \\
\text { Wash B }\end{array}$ & NM & $<10$ & 137 & 38 & $<10$ & & & \\
\hline
\end{tabular}

The ratios for the 10,000 ppm glycolate test showed more definitive physical carryover, given that there must have been enough to clearly measure for Water Wash A. The ratios do not indicate anything other than physical carryover. The $\mathrm{Na}$ /glycolate ratio is higher for Water Wash A than for $10,000 \mathrm{ppm}$ glycolate simulant, showing no evidence for a mechanism where glycolate would be soluble in the solvent phase.

Table 3-4 as well shows some evidence of physical carryover from simulant to water washes, but with glycolate at less than even physical levels. Note that physical carryover levels are indicated by the target and simulant $\mathrm{Na} /$ (analyte) ratios for aqueous high salt feeds being extracted. For example, $\mathrm{Na} /$ Glycol ratios exceeding 25.8 for the $5,000 \mathrm{ppm}$ glycolate simulant indicate less than physical carryover levels for glycolate. Therefore no glycolate solubility in solvent was seen under neutral $\mathrm{pH}$ conditions. 
Table 3-4. Contact Data for Neutral Simulant/Glycolate

\begin{tabular}{|l|l|l|l|l|l|l|l|l|}
\hline Simulant & Sodium & Nitrite & Nitrate & Sulfate & Glycolate & $\mathrm{Na} / \mathrm{S}$ & $\mathrm{Na} / \mathrm{NO} 3$ & $\mathrm{Na} / \mathrm{Glycol}$ \\
\hline $\begin{array}{l}5,000 \mathrm{ppm} \\
\text { Glycolate }\end{array}$ & 117,000 & 7,710 & 287,000 & 63,500 & 4,830 & 5.53 & 0.41 & 24.2 \\
\hline Target & 128,700 & 6,855 & 264,100 & 55,810 & 5,000 & 6.93 & 0.49 & 25.8 \\
\hline $\begin{array}{l}\text { Water } \\
\text { Wash A }\end{array}$ & 672 & 42 & 1,830 & 80 & $<10$ & 24.8 & 0.37 & $>67$ \\
\hline $\begin{array}{l}\text { Water } \\
\text { Wash B }\end{array}$ & $\mathrm{NM}$ & $<10$ & 282 & 17 & $<10$ & $\mathrm{NM}$ & $\mathrm{NM}$ & $\mathrm{NA}$ \\
\hline & & & & & & & & \\
\hline $\begin{array}{l}10,000 \\
\text { ppm } \\
\text { Glycolate }\end{array}$ & 117,000 & 6,900 & 272,000 & 57,000 & 9,400 & 6.16 & 0.43 & 12.5 \\
\hline Target & 128,700 & 6,855 & 264,100 & 55,810 & 10,000 & 6.93 & 0.49 & 12.9 \\
\hline $\begin{array}{l}\text { Water } \\
\text { Wash A }\end{array}$ & 705 & 43 & 1,930 & 105 & $<10$ & 19.4 & 0.37 & $>70$ \\
\hline & & & & & & & & \\
\hline $\begin{array}{l}\text { Water } \\
\text { Wash B }\end{array}$ & $\mathrm{NM}$ & $<10$ & 340 & 21 & $<10$ & $\mathrm{NM}$ & $\mathrm{NM}$ & $\mathrm{NA}$ \\
\hline
\end{tabular}

Table 3-5 shows data detecting some carryover of the caustic/no glycolate SWS-1-2010 simulant control from the high sodium phase to the water washes. The sodium/nitrate ratios are not far from each other (simulant vs. Water Wash A) but some deviation, probably caused by low analyte levels, is seen with the Water Wash B levels. The data indicate possible sodium carryover by a mechanism other than physical. Sulfate is a significant species in the salt simulant, yet the sodium/sulfate ratio shows additional sodium carryover. For the water washes the relatively small sodium values may have been biased high by residual sodium in the analyses as well. Sodium solubility in the solvent was not measured directly.

Table 3-5. Contact Data for Control Simulant - No Glycolate

\begin{tabular}{|c|c|c|c|c|c|c|}
\hline Simulant & Sodium & Nitrite & Nitrate & Sulfate & $\mathrm{Na} / \mathrm{S}$ & $\mathrm{Na} / \mathrm{NO} 3$ \\
\hline $\begin{array}{c}\text { Control, no } \\
\text { Glycolate, } \\
\text { Target }\end{array}$ & 128,700 & 6,855 & 179,800 & 55,810 & 6.92 & 0.72 \\
\hline $\begin{array}{c}\text { Water } \\
\text { Wash A }\end{array}$ & 723 & 24 & 922 & 53 & 35.1 & 0.78 \\
\hline $\begin{array}{c}\text { Water } \\
\text { Wash B }\end{array}$ & 36.6 & $<10$ & 28 & $<10$ & 35.9 & 1.31 \\
\hline
\end{tabular}




\subsection{Polymer Effects Testing Results}

PFA

Figures listed in Appendix A shows the gravimetric and dimensional changes data for PFA after two months of contact with a salt simulant, boric acid, and one-week exposure to NGS blended solvent followed by seven weeks exposure to salt simulant and boric acid. The data is shown as the difference between actual measurement and the initial measurement (before exposure). An observation of the data in Appendix A shows that all measurements fall within the error of the measurements. No substantial interaction between PFA and the salt simulant or boric acid containing sodium glycolate was detected. Hansen's prediction model is shown below.

\section{PVA}

Figures listed in Appendix B shows the dimensional and gravimetric data of PVA in contact with salt simulant, boric acid, and preconditioned with NGS blended solvent before it was added to the aqueous solutions. A glance at the data seems to indicate that PVA adsorbed some boric acid. However the remaining measurements were within the noise limits. Thus, there are not PVA and aqueous solution interactions. All measurements indicate that PVA was not affected by these aqueous solutions. Thus, there is no interaction between PVA and salt simulant containing sodium glycolate or boric acid containing sodium glycolate. Hansen's prediction model is shown below.

NBR

Figures listed in Appendix C shows the dimensional and gravimetric data of NBR in contact with salt simulant and boric acid containing sodium glycolate. Data from NBR preconditioned in NGS blended solvent is also shown in Appendix C. As can be seen from the figures, NBR exposed to NGS blended solvent got thicker ( $\sim 35 \%$ swelling) and heavier. The linear expansion was larger than the weight gained and thus the density of NBR exposed to NGS dropped below that of the as received NBR. Isopar ${ }^{\mathrm{TM}} \mathrm{L}$ permeated the NBR rubber as expected since both NBR and Isopar ${ }^{\mathrm{TM}}$ $\mathrm{L}$ have components with strong dispersion forces. At the same time, NBR leached a low molecular weight alkane into the NGS blended solvent which might explain the large increase in NBR dimensions. NBR got softer when it contacted MCU solvent for two months. Since NBR is used as an O-ring, the polymer is confined usually between flanges. The space constraint impedes the NBR from expanding and thereby, reducing the effect of NGS blended solvent on NBR. Thus, the current O-rings used at MCU are not in danger if they come in contact with sodium glycolate. No additional dimensional changes or net weight changes were observed in NBR in the presence of Glycolate. Again, this observation is consistent with Hansen's predictions that sorbing Isopar ${ }^{\mathbb{R}} \mathrm{L}$ increases the dispersion component in the NBR polymer and making less attractive to the more polar glycolate (or more hydrogen bonding glycolic acid) as shown below.

\section{Hansen's Predictions}

Hansen established correlation numbers between the interaction energy (the cohesive energy density) needed to evaporate a pure liquid and the molecular group constituents of the molecules that make up the liquid. ${ }^{13}$ Using Hansen's correlation numbers and the "like dissolves like" criteria, one can determine the compatibility (interaction or lack of it) between two or more components in a mixture. The Hansen's parameters are broken down in to a dispersion, polar, and hydrogen bonding (Lewis acid and bases) components to capture the global interaction capability of a molecule. In this case, the Hansen's solubility parameters for water, glycolic acid, PFA, PVAcetal, and NBR are listed in Table 3-6. As recommended by Hansen, Table 3-6 shows the "radius ratio" which is the ratio of the distance between the Hansen's parameters of two chemicals (in this case is glycolic acid and the polymers) to the interaction radius (determined 
empirically) of the polymer. According to Hansen, if the "radius ratio" of two chemicals is one or larger, the two chemicals are dissimilar and will not interact. An inspection of Table 3-6 shows that the radius ratio of glycolic acid and NBR is 0.9. This suggests a borderline interaction between glycolic acid and NBR. However, a closer inspection of Table 3-6 shows that NBR has negligible hydrogen bonding capability and thus, glycolic acid will interact more favorably with self-associated water (due to similar Hansen's numbers) than with NBR. Thus, glycolic acid is not expected to interact with NBR or PFA or PVAcetal. This prediction is consistent with the experimental data discussed earlier.

Table 3-6. Hansen's prediction of Glycolate interaction with PFA, PVAcetal, and NBR

\begin{tabular}{|c|c|c|c|c|c|c|c|}
\hline Component & $\begin{array}{c}\text { Dispersion } \\
\sqrt{\mathrm{MPa}^{*}}\end{array}$ & $\begin{array}{c}\text { Polar } \\
\sqrt{\mathrm{MPa}} \\
*\end{array}$ & $\begin{array}{c}\text { Hydrogen Bonding } \\
\sqrt{\mathrm{MPa}^{*}}\end{array}$ & $\begin{array}{c}\text { Total } \\
\sqrt{\mathrm{MPa}}\end{array}$ & $\begin{array}{c}\mathrm{cm}^{\wedge} 3 / \\
\mathrm{mol}^{*}\end{array}$ & $\begin{array}{c}\text { Interaction } \\
\text { Radius } \\
\sqrt{\mathrm{MPa}^{*}}\end{array}$ & $\begin{array}{c}\text { Radius } \\
\text { Ratio }^{\#}\end{array}$ \\
\hline Glycolic Acid & 17.3 & 9.1 & 16.3 & 25.5 & 54.9 & - & NA \\
\hline PFA & 16.7 & 7.7 & -0.5 & 18.4 & 16.7 & 8.1 & $\mathbf{2 . 1}$ \\
\hline NBR & 19.8 & 17.8 & 3.2 & 26.8 & 19 & 19 & $\mathbf{0 . 9}$ \\
\hline PVAcetal & 21 & 9.3 & 5.9 & 23.7 & 21.1 & 11.4 & $\mathbf{1 . 1}$ \\
\hline $\begin{array}{c}\text { H2O with } \\
\text { organic acid }\end{array}$ & $12-16$ & $16-31$ & $34-42$ & 48.0 & 18 & 18.1 & NA \\
\hline $\begin{array}{c}\text { H2O } \\
\text { self-associated }\end{array}$ & 20 & 18 & 18 & 32.0 & 18 & 13.9 & NA \\
\hline
\end{tabular}

*Hansen's solubility parameters were obtained from C. M. Hansen, 1983, "Hansen Solubility Parameters: A User Handbook," CRC Press, Boca Raton FL.

"Solubility calculations were done as recommended in Van Krevelen, D. W. and Hoftyzer, P. J., 1976 " Properties of Polymers," 2nd Ed. Elsevier, NY.

\subsection{Extraction, Scrub, Strip Testing Results}

There were three ESS test performed which were designed to investigate the effect of DWPF recycle containing sodium glycolate on the efficiency of the caustic-side solvent extraction process. The three tests varied only in the amount of sodium Glycolate added to the aqueous feed where $10,000 \mathrm{ppm}, 5,000 \mathrm{ppm}$, and $0 \mathrm{ppm}$ solutions were created. If glycolate had an effect on the behavior of the cesium distribution, this would be observed as poor extraction, scrubbing, or stripping performance.

For each ESS test, after each step, a sample of each phase was measured for ${ }^{137} \mathrm{Cs}$ activity. From these measurements, the $\mathrm{D}_{\mathrm{Cs}}$ can be determined;

$\mathrm{D}_{\mathrm{Cs}}={ }^{137} \mathrm{Cs}$ activity in the organic phase $/{ }^{137} \mathrm{Cs}$ activity in the aqueous phase

While the temperature in the shielded cells during the ESS test only ranged from $24.1{ }^{\circ} \mathrm{C}$ to $26.2{ }^{\circ} \mathrm{C}$, the temperature was measured for each step. This is important, as the extraction and scrub data must be temperature corrected to $23{ }^{\circ} \mathrm{C}$, while the strip data must be corrected to 33 ${ }^{\circ} \mathrm{C} .{ }^{14}$ The temperature correction factors are the ones used for pure NGS solvent, and it is assumed that the NGS blend solvent will have the same temperature dependence.

Table 3-7 shows the $\mathrm{D}_{\mathrm{Cs}}$ values from the three ESS tests, and the expected $\mathrm{D}_{\mathrm{Cs}}$ value ranges for NGS MaxCalixC6 solvent. As a comparison, the previous results from the NGS blend ESS test 
completed in January 2014 (Salt Batch 7) from the Tank 21 material are included. ${ }^{15}$ Strictly speaking, a comparison to the Salt Batch 6 results would be a more appropriate comparison (the aqueous phase was the same), except the ESS testing with that material used the old BOBCalixC6 solvent. Therefore, the comparison is made to the more recent Salt Batch 7 results, which used a slightly different aqueous phase material. The LWHT material is diluted by $\sim 2.84 \%$ from the Tank 49/Tank 21 material as a result of the actinide removal process (N-NCS-H-00192).

Table 3-7. ${ }^{137}$ Cs Distribution $\left(\mathrm{D}_{\mathrm{Cs}}\right)$ Results

\begin{tabular}{|c|c|c|c|c|c|c|}
\hline Material & $\begin{array}{c}\text { Extraction } \\
\mathrm{D}_{\mathrm{Cs}} \\
\end{array}$ & $\begin{array}{c}\text { Scrub\#1 } \\
\mathrm{D}_{\mathrm{Cs}}\end{array}$ & $\begin{array}{c}\text { Scrub\#2 } \\
\mathrm{D}_{\mathrm{Cs}} \\
\end{array}$ & $\begin{array}{c}\text { Scrub\#3 } \\
\mathrm{D}_{\mathrm{Cs}}\end{array}$ & $\begin{array}{c}\text { Strip\#1 } \\
\mathrm{D}_{\mathrm{Cs}} \\
\end{array}$ & $\begin{array}{c}\text { Strip\#2 } \\
\mathrm{D}_{\mathrm{Cs}}\end{array}$ \\
\hline $\begin{array}{c}\text { Expected Range, } \\
\text { NGS MaxCalixC6 Solvent }\end{array}$ & $50-70$ & $>3,<5$ & $>3,<5$ & unknown & $<0.05$ & $<0.05$ \\
\hline 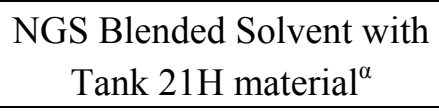 & 59.4 & 4.58 & 2.91 & NA & 0.00184 & 0.0252 \\
\hline $\begin{array}{c}\text { NGS LWHT 512-S } \\
\text { without Glycolate added }\end{array}$ & 66.1 & 5.98 & 4.31 & 3.38 & 0.0386 & 0.00514 \\
\hline $\begin{array}{l}\text { NGS LWHT 512-S with } \\
\text { 5,000 ppm Glycolate }\end{array}$ & 68.3 & 5.81 & 3.50 & 3.24 & 0.0177 & 0.00104 \\
\hline $\begin{array}{l}\text { NGS LWHT 512-S with } \\
10,000 \text { ppm Glycolate }\end{array}$ & 65.9 & 13.39 & 3.44 & $5.34^{*}$ & 0.0788 & 0.256 \\
\hline
\end{tabular}

${ }^{\alpha}$ Data taken from ESS report: SRNL-STI-2013-00740, used MCU BOBCalixC6 solvent mixed with fresh NGS solvent and Tank 21 material. ${ }^{16}$

* Due to insufficient sample, the cesium activity for the organic sample was calculated assuming a $100 \%$ activity balance

For the three NGS blend solvent ESS tests, the data shown in Table 3-7 are mostly in the expected ranges for the NGS blended solvent program. The expected value for extraction with NGS has a range from 50-70 which is fully supported by the tabulated values. This is the key point - the presence or absence of glycolate has no meaningful impact on the extraction distribution of cesium. This is the same conclusion reached in previous glycolate-ESS testing with other solvents. ${ }^{2}$

Two of the Scrub\#1 values were slightly outside the typical ranges, but not unusually so. However, the Scrub\#1 in the $10,000 \mathrm{ppm}$ sample set has a scrub value noticeably higher than typical. As other tests in this document conclude that glycolate does not transfer to the solvent phase, any unusual effects in scrubbing or stripping stages cannot be due to glycolate. Therefore, the result in these scrub phases are most likely attributed to inadequate mixing, phase carryover, ${ }^{\nabla}$ or analytical variances. Furthermore, due to insufficient sample volume, the organic phase ${ }^{137} \mathrm{Cs}$ activity for the $10,000 \mathrm{ppm}$ glycolate test Scrub\#3 step had to be calculated by assuming a $100 \%$ activity balance. ${ }^{\Pi}$

\footnotetext{
$\nabla$ Recall that the phase separation is performed using a set of remote manipulators, while trying to view the phase delineation of two virtually transparent phases through 4 feet of leaded glass.

${ }^{\Pi}$ Activity balance is defined as the sum total ${ }^{137} \mathrm{Cs}$ activities in the output phases divided by the sum total of the ${ }^{137} \mathrm{Cs}$ activities in the input phases. As there is little leakage or unaccountable loss of phases, this value should theoretically be very close to 1 , or $100 \%$.
} 
As described in the experimental section, a third scrub was performed for the testing. For Scrub\#3 the temperature correction coefficient of scrub\#2 was used, as a temperature correction factor for scrub\#3 is unknown and must be experimentally determined.

The strip $\mathrm{D}_{\mathrm{Cs}}$ values are largely as expected (including the apparent large variations), although the $10,000 \mathrm{ppm}$ case appears to be exhibiting poor stripping performance. However, as other tests in this document conclude that there is no measurable uptake of glycolate into the solvent (to a detection limit of $10 \mathrm{mg} / \mathrm{L}$ ), any unusual effects in scrubbing or stripping stages cannot be due to glycolate. If a concentration of glycolate below the detection limit would be sufficient to degrade the solvent performance, then this effect would have been noted in the $5000 \mathrm{ppm}$ glycolate test.

Therefore, the strip results in this particular test are most likely attributed to inadequate mixing, phase carryover, or analytical variances.

Table 3-8 lists the resulting $\mathrm{pH}$ values from the aqueous phase from each step in each ESS test, other than the extraction step. These values were measured by 4 point colorimetric strips and are subject to interference from the poor lighting in the cells and colored cell windows.

Table 3-8. pH Values for Glycolate ESS Tests

\begin{tabular}{|c|c|c|c|c|c|c|}
\hline Materials & $\underline{\text { Extraction }}$ & $\underline{\text { Scrub \#1 }}$ & $\underline{\text { Scrub \#2 }}$ & $\underline{\text { Scrub \#3 }}$ & $\underline{\text { Strip \#1 }}$ & $\underline{\text { Strip \#2 }}$ \\
\hline Glycolate 0 ppm & N/A & 11 & 13 & 14 & 7 & 8 \\
\hline Glycolate 5,000 ppm & N/A & 14 & 10 & 14 & 7 & 7 \\
\hline $\begin{array}{c}\text { Glycolate 10,000 ppm } \\
\text { pH of aq. phase as } \\
\text { prepared }\end{array}$ & N/A & 14 & 13 & 14 & 8 & 9 \\
\hline
\end{tabular}

The $\mathrm{pH}$ values for the scrub\#3 steps are conclusive proof that this step is in fact a scrub step and not a strip step.

\subsection{Conclusions}

- Dispersion testing showed that 5,000 and $10,000 \mathrm{ppm}$ glycolate had no effect on the ability of the new guanidine solvent to separate from aqueous phases.

- Washing of solvent that had contacted glycolate-containing simulants at neutral and at high (14) $\mathrm{pH}$ showed no evidence that glycolate is soluble in MAX/TiDG type solvent. The tests were likely very sensitive so that if glycolate was soluble, it would be seen. The tests washed the solvent with pure water at less than simulant contact volumes, so that possible concentration of glycolate extracted from the solvent would have been seen.

- No dimensional changes or net weight changes were observed for the three polymers tested (PVAcetal, PVF, and NBR) in the presence of 10,000 ppm sodium glycolate or glycolic acid. NBR experienced swelling $(\sim 35 \%)$ in NGS solvent but that swelling did not increase any pre-existing interaction between NBR and glycolate.

- ESS testing of 0, 5,000, and 10,000 ppm showed no Glycolate-induced decrease in the performance of the extraction, scrub, or stripping tests. 
SRNL-STI-2014-00369

Revision 0

\subsection{Path Forward}

This work essentially completes the recommended materials testing of the past glycolate testing. ${ }^{2}$ If it is found that glycolate in feed to MCU can exceed 10,000 ppm, it is recommended that solvent and materials issues be revisited. 


\subsection{References}

${ }^{1}$ D. P. Lambert, M. E. Stone, J. D. Newell, D. R. Best, and J. R. Zamecnik, "Glycolic-Nitric Acid Flowsheet Demonstration of the DWPF Chemical Process Cell with Sludge and Supernate Simulants, SRNL-STI-2012-00018, Revision 1, August 2012.

${ }^{2}$ K. M. L. Taylor-Pashow, T. B. Peters, F. F. Fondeur, T. C. Shehee, and A. L. Washington, "Determination of the Impact of Glycolate on ARP and MCU Operations", SRNL-STI-2012-00218, rev. 1, December 2012.

${ }^{3}$ E. Ketusky, "Recommended Quantities of Solvent Constituents for Next Generation Solvent (NGS)", SRR-SPT-2012-00039, November 7, 2012.

${ }^{4}$ T. L. Fellinger, TTR "Nitric/Formic/Glycolic Flowsheet Tasks - Determination of Fe/Pu Solubility and Impact to Solvent Extraction", HLW-DWPF-TTR-2011-0025, rev. 4, June 19, 2013.

${ }^{5}$ C. A. Nash, T. B. Peters, and F. F. Fondeur, "Task Technical and Quality Assurance Plan for Glycolate and New Guanidine Solvent Testing for MCU”, SRNL-RP-2014-00197, rev. 0, March 2014.

${ }^{6}$ R. A. Leonard, "Solvent Characterization Using the Dispersion Number", Sep. Sci. and Tech., vol. 30 (7-9), pg. 1103-1122, 1995.

${ }^{7}$ T. B. Peters, "Dispersion Number Testing for Mixed Aqueous-Organic Mixtures", Work Instruction IWPT-012, rev. 1, October 4, 2011.

${ }^{8}$ Inci, I., "Distribution of Glycolic Acid Between Water and Different Organic Solutions", Chemical and Biochemical Engineering Quarterly, vol. 16(2), pp. 81-85 (2002).

9 Asci, Y. S., and Inci, I., "Extraction of Glycolic Acid from Aqueous Solutions by Amberlite LA-2 in Different Diluent Solvents", Journal of Chemical Engineering Data, Vol., 54, pp. 2792-2794 (2009).

${ }^{10}$ C. J. Martino, D. T. Herman, J. A. Pike, T. B. Peters, “Actinide Removal Process Sample Analysis, Chemical Modeling, and Filtration Evaluation”, SRNL -STI-2013-00700, June 2014.

${ }^{11}$ T. B. Peters, "Extraction, Scrub and Strip testing of Solvent Extractions System", SRNL Manual L29, ITS-0205, rev. 0, September 2013.

12 D. T. Herman, M. R. Duignan, M. R. Williams, T. B. Peters, M. R. Poirier, and F. F. Fondeur, "Mass Transfer and Hydraulic Testing of the V-05 and V-10 Contactors with the Next Generation Solvent", SRNL-STI-2013-00413, rev. 0, July 2013.

${ }^{13}$ C. M. Hansen, C. M., "Hansen Solubility Parameters: A User Handbook," CRC Press, Boca Raton FL (1983).

${ }^{14}$ N. J. Williams, B. A. Moyer, "Temperature Dependence of the Next Generation Caustic Side Solvent Extraction (NG-CSSX) Process Solvent,” ORNL-LTR-NGCSSX, August 5, 2011.

${ }^{15}$ T. B. Peters, A. L. Washington. "Sample Results from the Interim Salt Disposition Program Macrobatch 7 Tank 21H Qualification Samples", SRNL-STI-2013-00437, July 2013.

${ }^{16}$ A. L. Washington, T. B. Peters, "Sample Results from the Extraction, Scrub, and Strip Test for the Blended NGS Solvent”, SRNL-STI-2013-00740, Rev. 0, March 2014. 


\section{Appendix A: PFA Physical Measurements}

Figure A-1. The Thickness of PFA after two months of contact with different aqueous solutions containing Glycolate

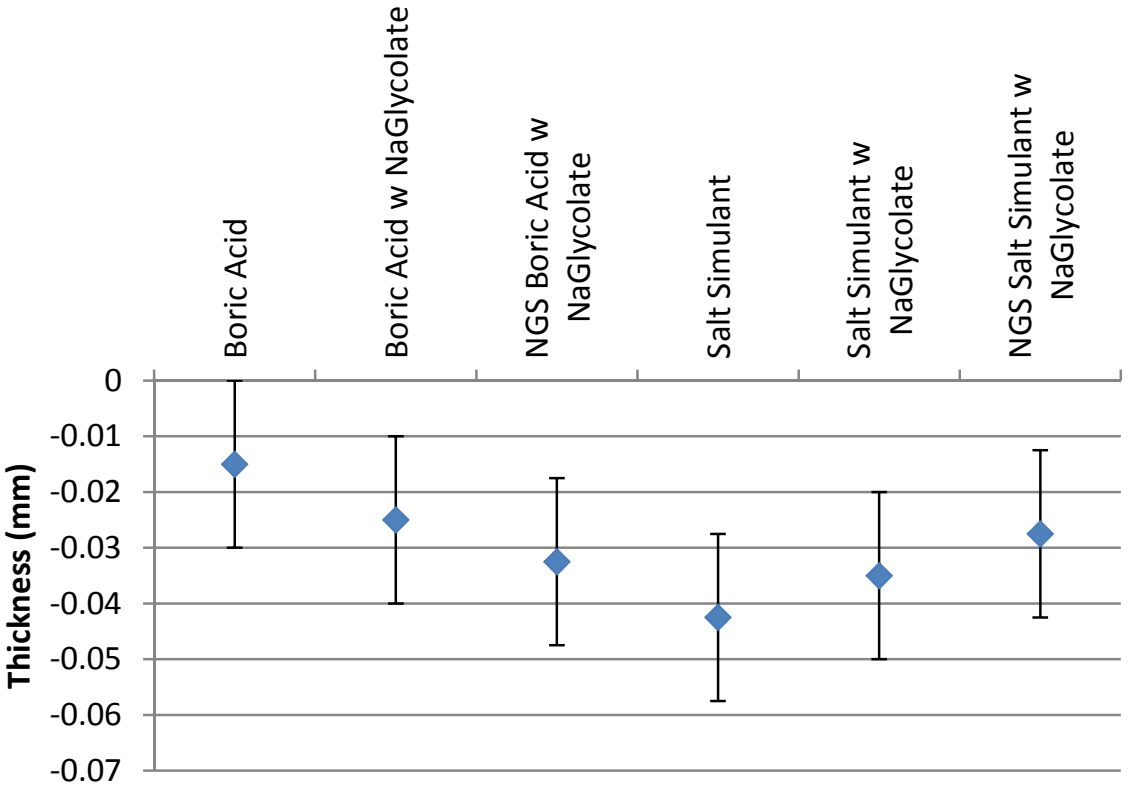

Figure A-2. The diameter of PFA after two months of contact with different aqueous solutions containing Glycolate

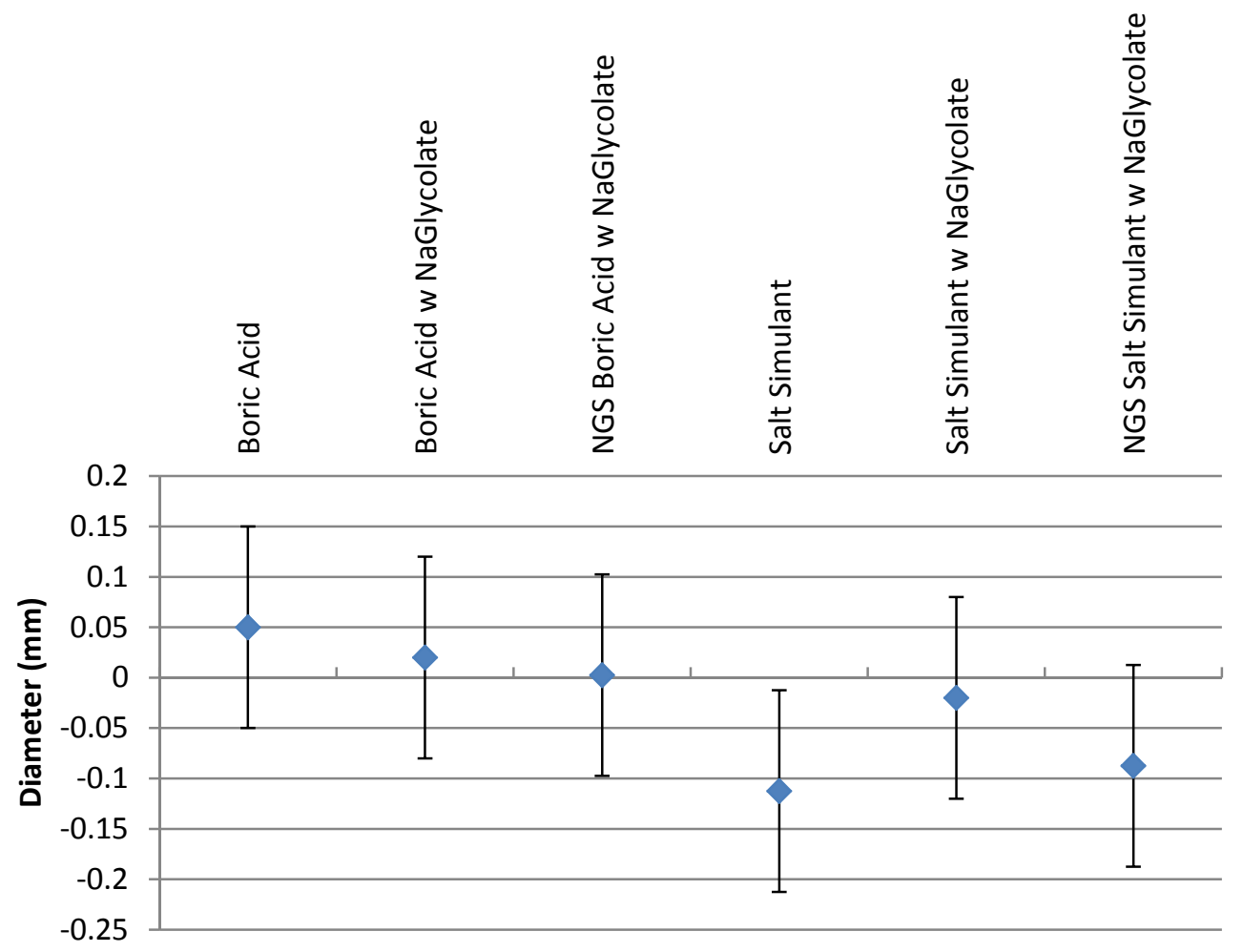


Figure A-3. The net weight of PFA after two months of contact with different aqueous solutions containing Glycolate

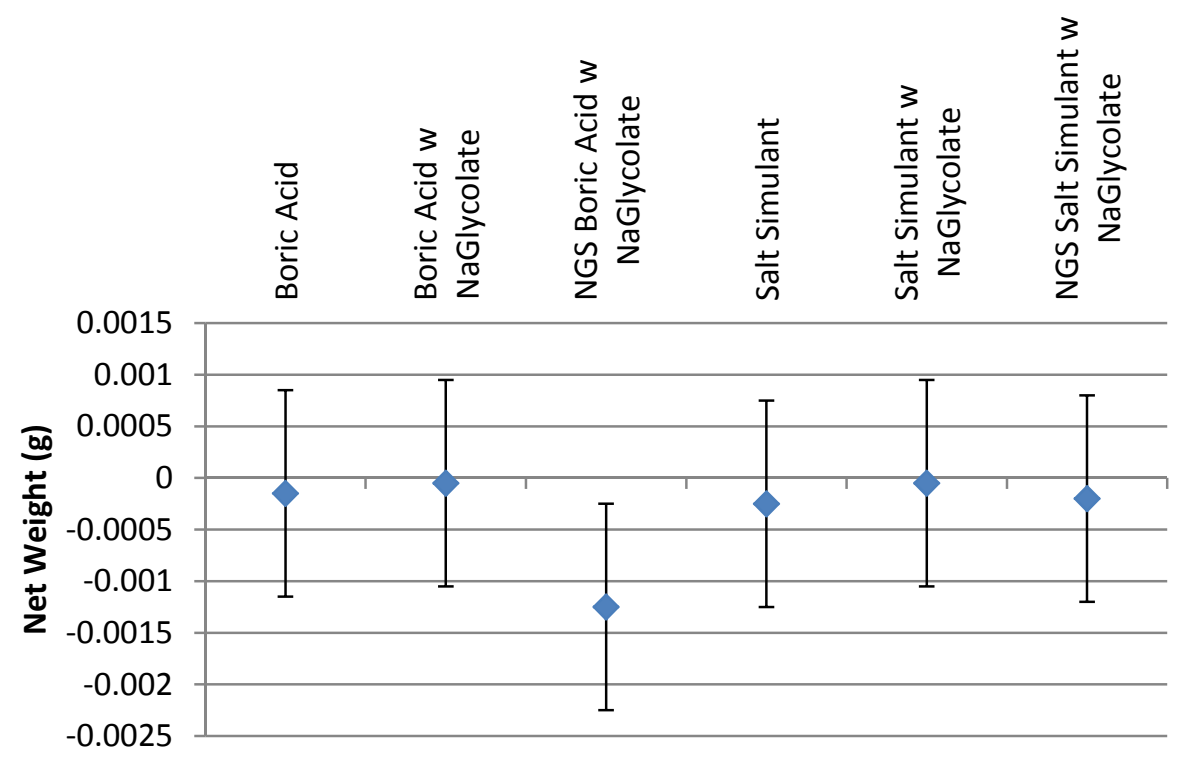

Figure A-4. The density of PFA after two months of contact with different aqueous solutions containing Glycolate

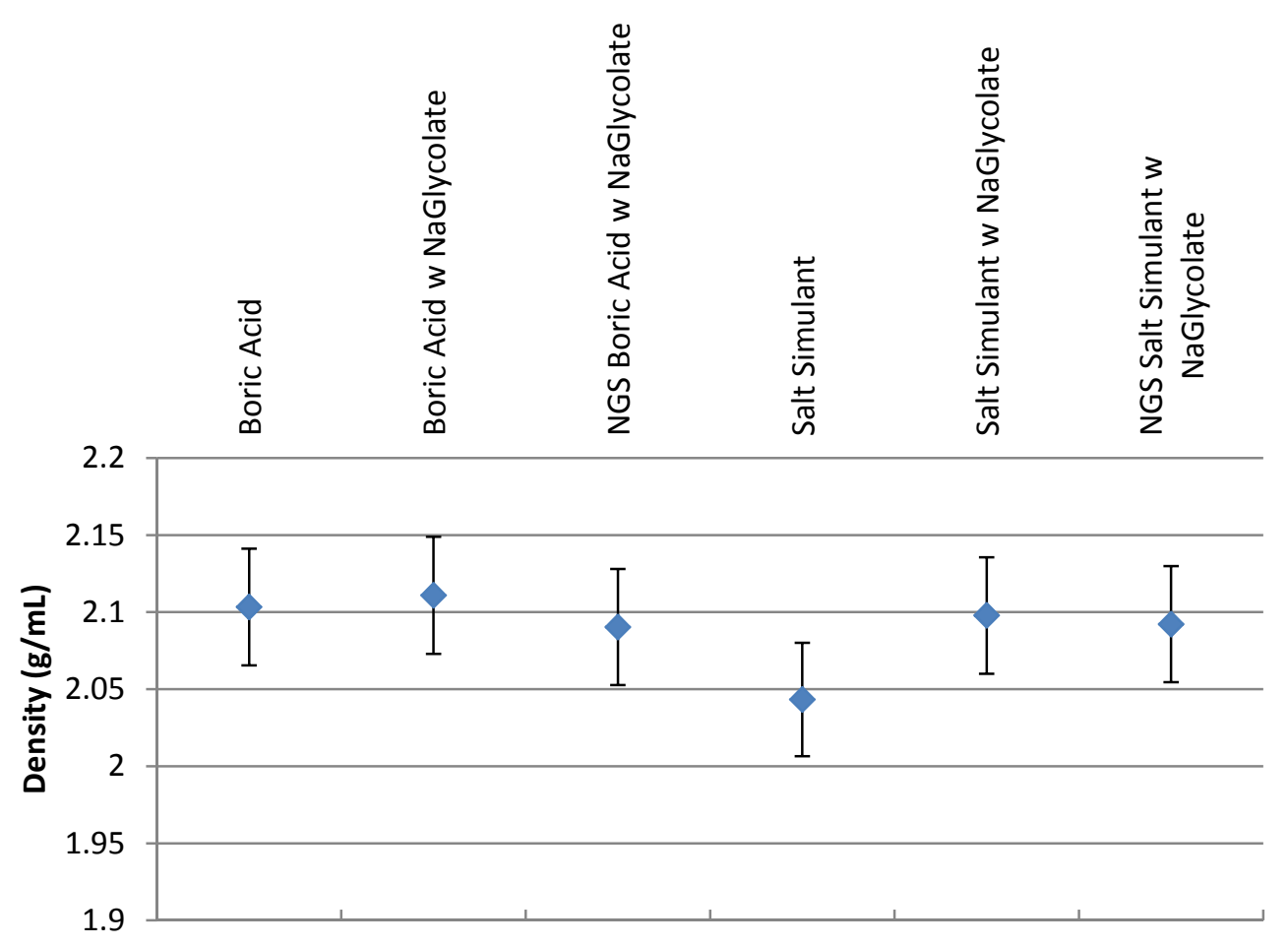


SRNL-STI-2014-00369

Revision 0

Figure A-5 The hardness of PFA after two months of contact with different aqueous solutions containing Glycolate

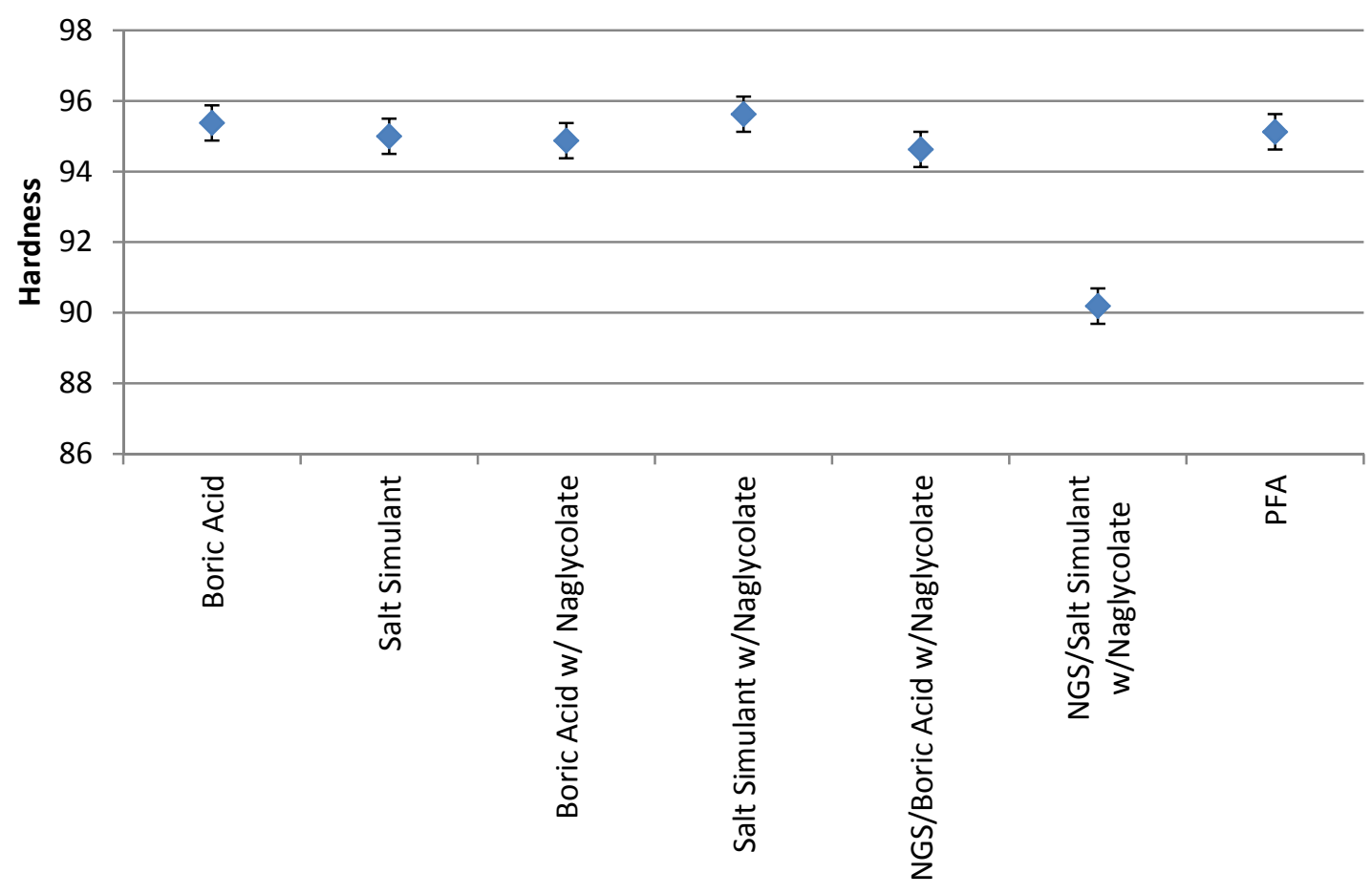


SRNL-STI-2014-00369

Revision 0

Appendix B: Physical Measurements of PVA

Figure B-1. The diameter of PVA after two months of contact with different aqueous solutions containing Glycolate

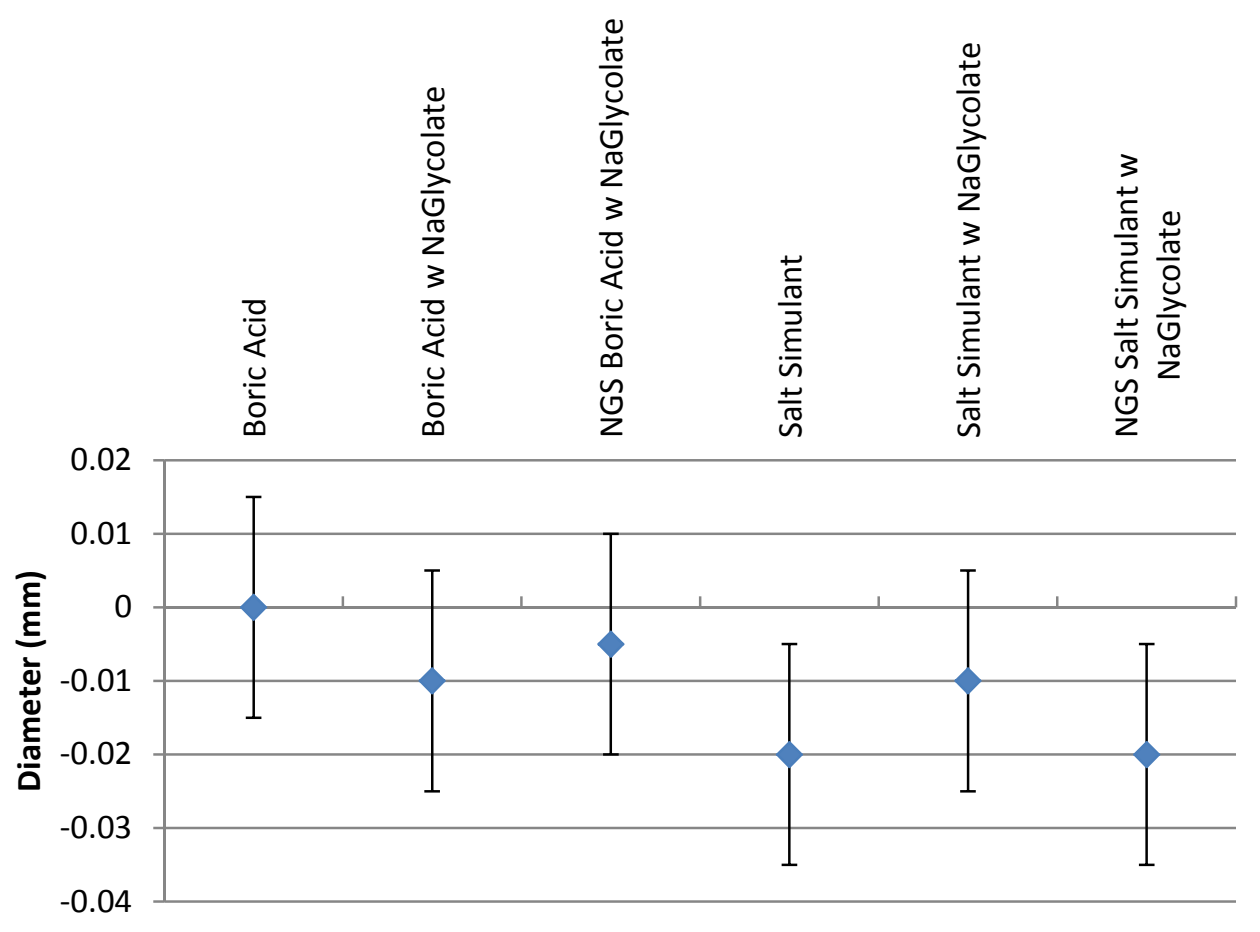

Figure B-2. The net weight of PVA after two months of contact with different aqueous solutions containing Glycolate

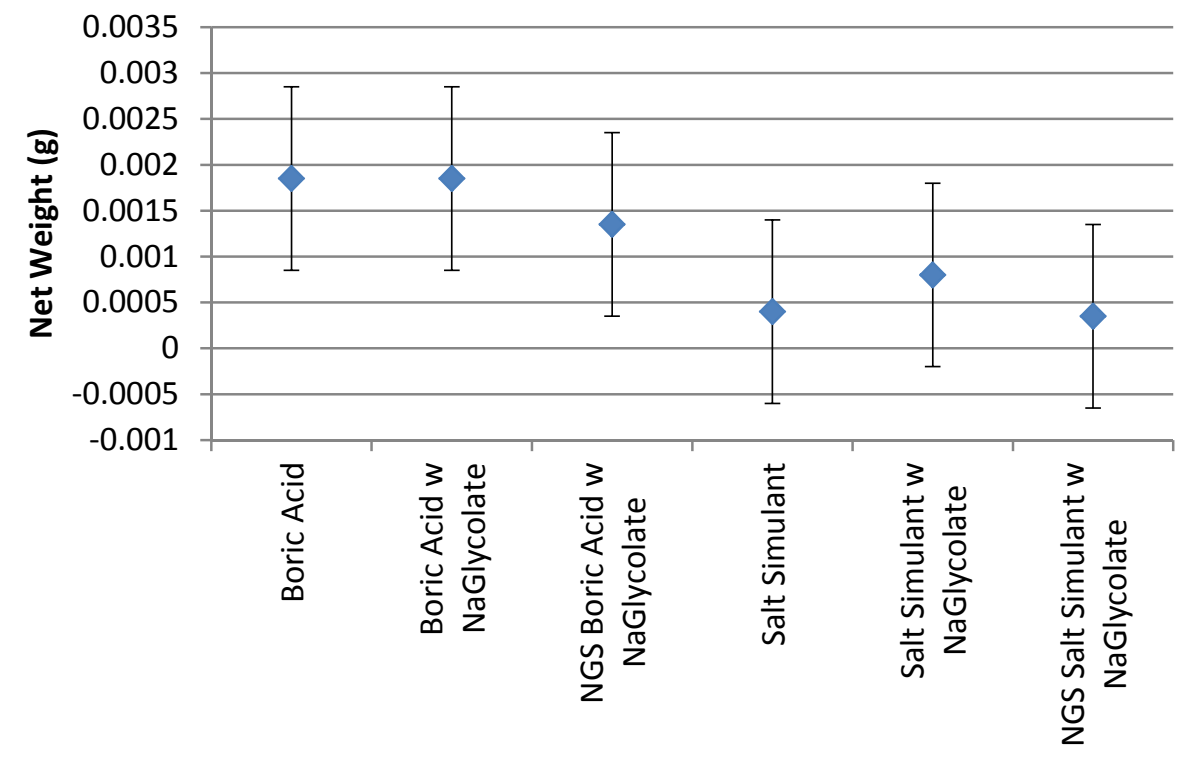


Figure B-3. The density of PVA after two months of contact with different aqueous solutions containing Glycolate

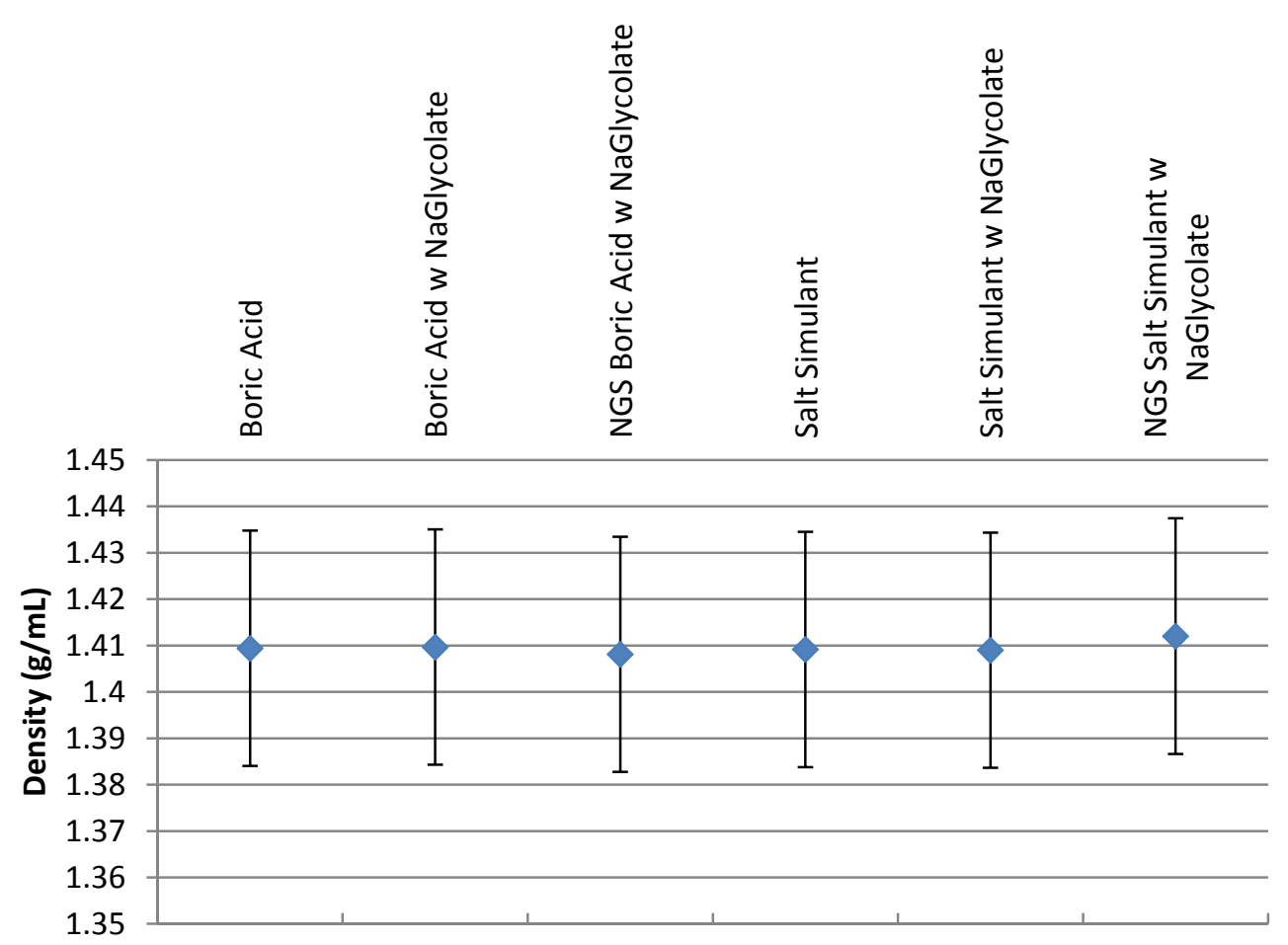

Figure B-4. The hardness of PVA after two months of contact with different aqueous solutions containing Glycolate

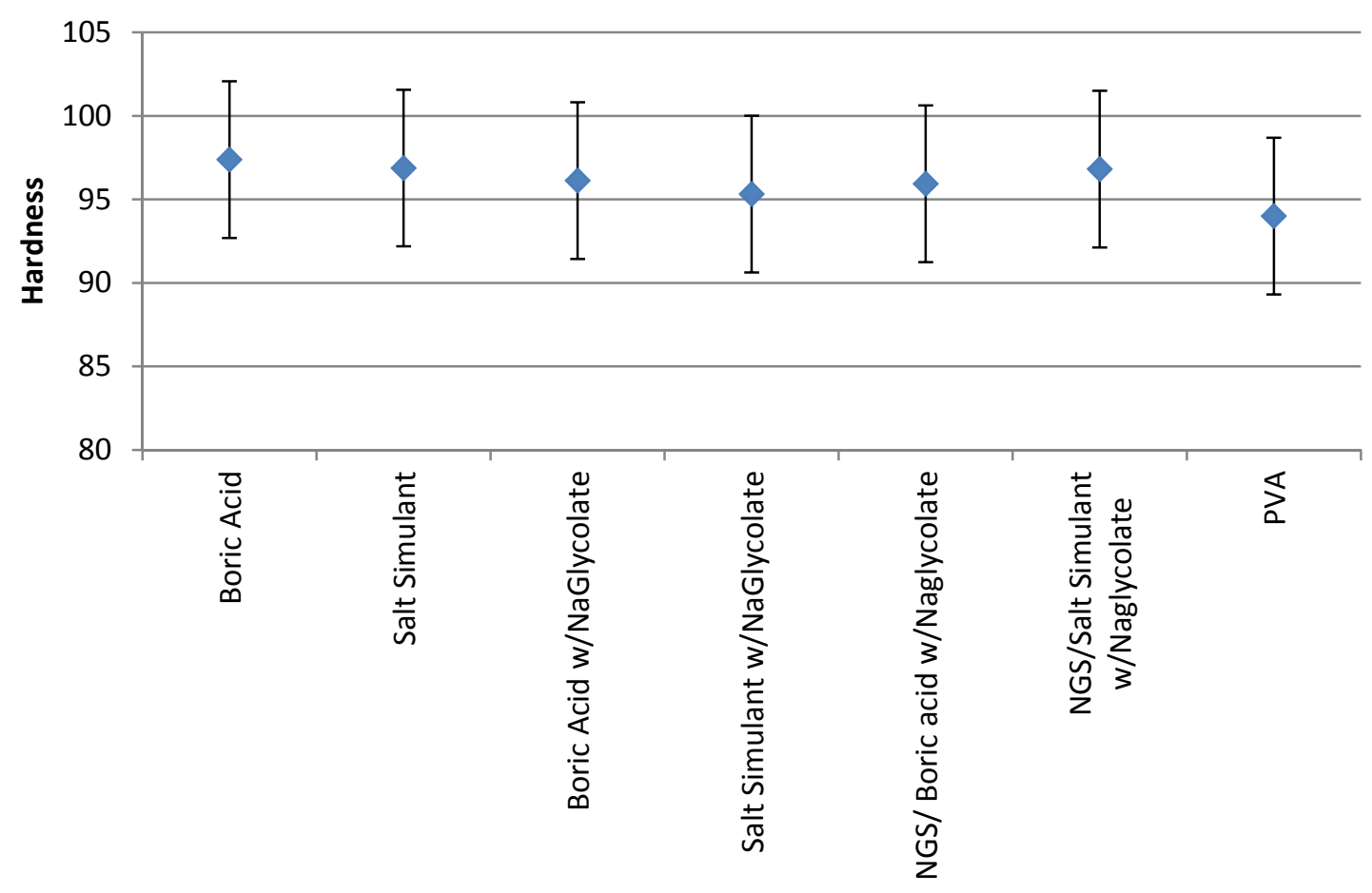


SRNL-STI-2014-00369

Revision 0

Appendix C: Physical Measurements of NBR

Figure C-1. The thickness of NBR after two months of contact with different aqueous solutions containing Glycolate
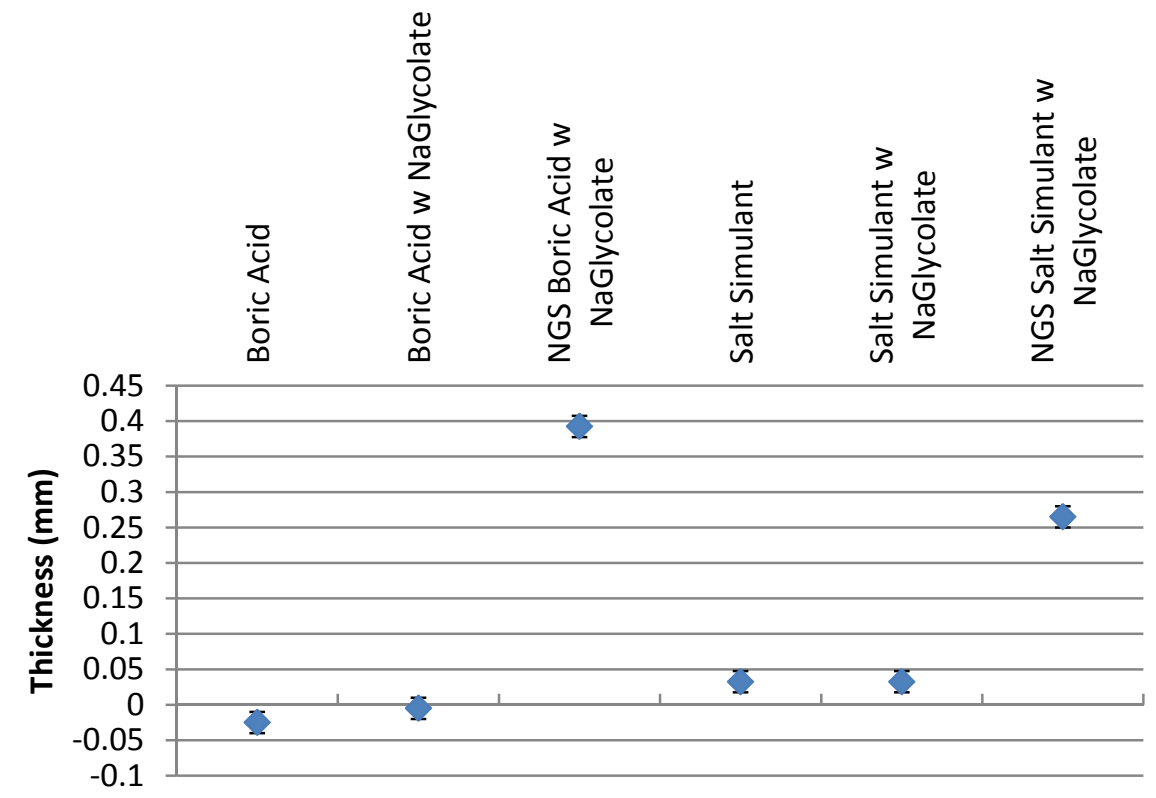

Figure C-2. The net weight of NBR after two months of contact with different aqueous solutions containing Glycolate

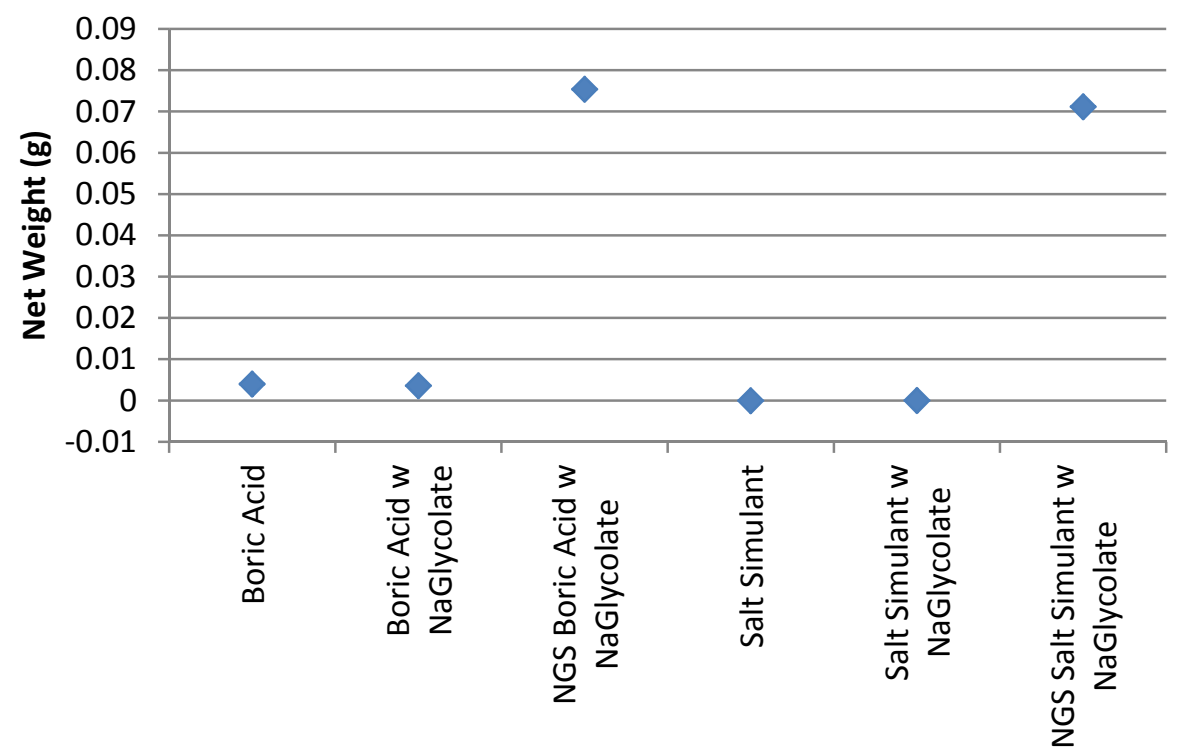


Figure C-3. The hardness of NBR after two months of contact with different aqueous solutions containing Glycolate

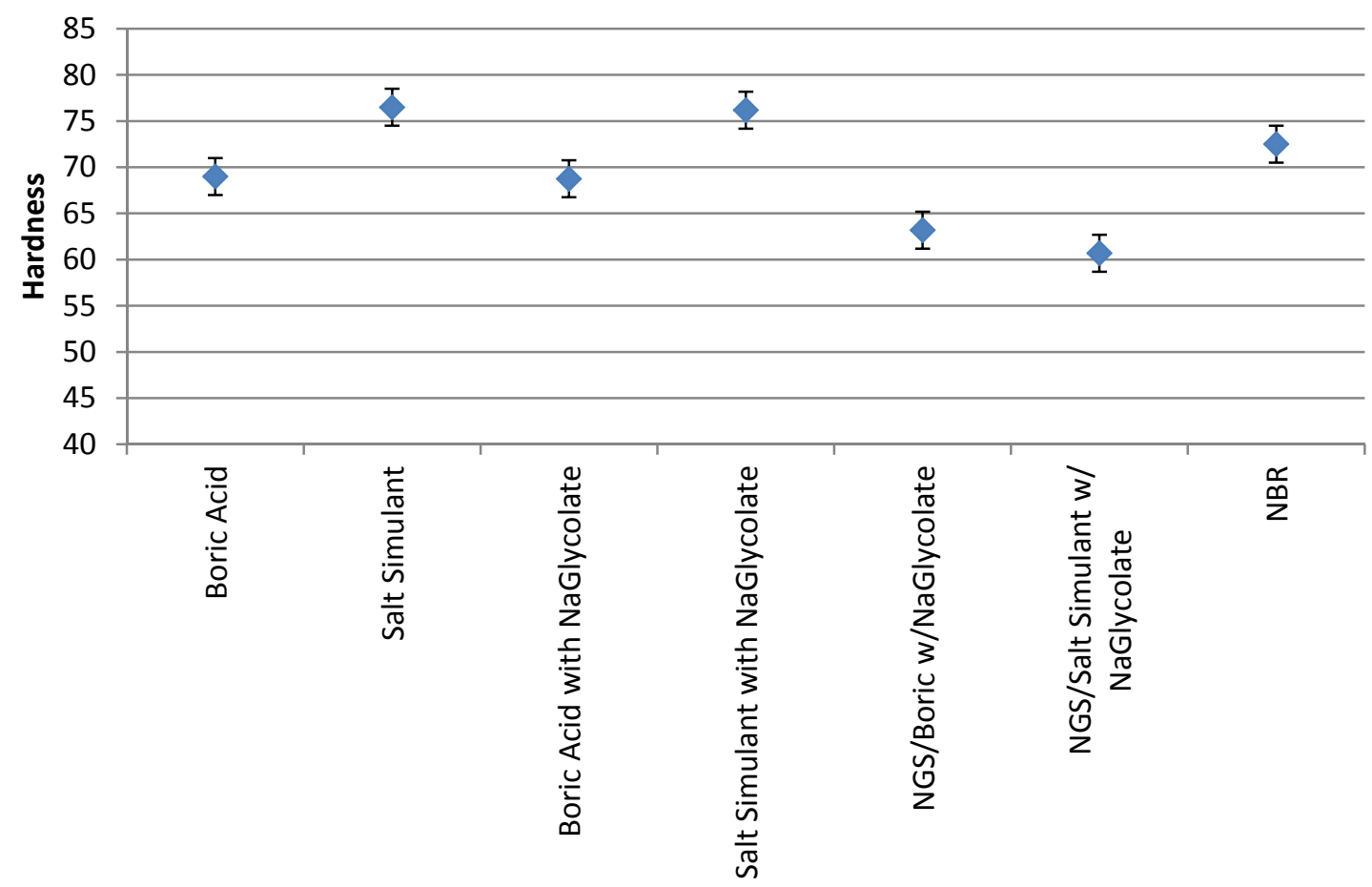




\section{Distribution:}

S. L. Marra, 773-A

F. M. Pennebaker 773-42A

T. B. Brown, 773-A

S. D. Fink, 773-A

C. C. Herman, 773-A

E. N. Hoffman, 999-W

D. H. McGuire, 999-W

W. R. Wilmarth, 773-A

Records Administration (EDWS)

E. A. Brass, 249-8H

C. J. Scherman, 241-152H

Q. L. Nguyen, 241-152H

S. T. Isom, 766-H

E. J. Freed, 704-S

A. G. Garrison, 248-9H

B. A. Gifford, 704-56H

T. A. Le, 766-H

D. J. Martin, 241-152H

T. E. Smith, 241-152H

R. McNew, 241-152H

A. R. Shafer, 704-27S

T. L. Fellinger, 766-H

E. W. Holtzscheiter, 766-H

C. A. Nash, 773-42A

T. B. Peters, 773-42A

A. L. Washington II, 773-42A

C. J. Martino, 773-42A

F. F. Fondeur, 773-A

P. R. Jackson, DOE-SR, 703-46A 